\title{
OS DIREITOS SOCIAIS E A TEORIA DISCURSIVA DO DIREITO
}

\author{
Cláudio ARI Mello*
}

Introdução. I-Classificação dos Direitos Fundamentais: 1. Classificação dimensional; 2. Classificação dogmática; 3. Classificação histórica; II Normas constitucionais quanto à eficácia. 111 - Concepção programática das normas constitucionais de direitos sociais: 1 . Crítica à natureza semântica e estática das teorias dogmáticas das normas constitucionais; 2. A teoria discursiva do Direito e a eficácia dos direitos sociais; IV-Objeções: 1. Cobertura insuficiente; 2. Ilegitimidade democrática; 3. Usurpação de competências; Considerações finais.

\section{Introdução}

Um dos fenômenos políticos mais significativos das últimas décadas do século $\mathrm{XX}$ foi a restauração e a consolidação do constitucionalismo como teoria e prática de organização de sociedades justas. À margem da sua permanência na Grã-Bretanha e na América do Norte sem solução de continuidade desde que, nos séculos XVII e XVIII, foi gestado e adotado, o constitucionalismo sofreu poderoso abalo desde a primeira guerra mundial, não apenas na Europa mas em todo o mundo ocidental, incluindo a América Latina, que experimentou a substituição gradativa de suas inseguras repúblicas por ditaduras civis e militares absolutamente avessas ao regime constitucional.

A reconstrução política e econômica da Europa após a segunda guerra mundial seria decisiva na mudança radical desse panorama. Os paradigmas do rule of law britânico e da constituição escrita e rígida norte-americana, com garantia de direitos individuais e limites ao exercício do poder influenciaria vigorosamente a engenharia política e jurídica desse período; as constituições que são elaboradas desde então, conquanto incorporem aspectos desconhecidos pelo constitucionalismo anglo-ame-

* Promotor de Justiça do Ministério Público do Rio Grande do Sul e Professor de Direito Constitucional do Campus-II da Pontifícia Universidade Católica do Rio Grande do Sul, em Uruguaiana.

R. Dir. Adm.,

Rio de Janeiro, 224: 239-284, abr./jun. 2001 
ricano, como os direitos sociais e econômicos, e mesclem-nos com características dos sistemas jurídicos e políticos locais, compartilham do anseio generalizado de construir regimes políticos estáveis e democráticos, infensos a governos autoritários e capazes de assegurar o respeito aos direitos fundamentais do homem, tal como experimentaram os países anglo-americanos sob a supremacia do constitucionalismo.

Uma das caraterísticas centrais do constitucionalismo sucessivo à segunda guerra é a ênfase posta na garantia dos direitos fundamentais. É verdade que o constitucionalismo moderno esteve sempre ancorado em dois pólos básicos: a garantia dos direitos individuais do homem e a limitação do poder, do que o célebre artigo $16 \mathrm{da}$ Declaração dos Direitos do Homem e do Cidadão de 1789 e a Constituição norteamericana são evidências eloqüentes ${ }^{1}$. Mas se a doutrina e prática constitucionais tradicionais visaram sempre a estabelecer um equilíbrio entre a organização do poder político e a tutela dos direitos fundamentais, o constitucionalismo contemporâneo privilegiará nitidamente a garantia dos direitos, submetendo a esse fim a organização política do Estado.

A essa ancoragem do constitucionalismo na garantia dos direitos do homem, acrescentou-se o fenômeno da expansão quantitativa e qualitativa dos direitos considerados fundamentais. As constituições passam a proteger não apenas os direitos individuais liberais, mas também os direitos sociais, econômicos e culturais, tal como o constitucionalismo do entre-guerras já prenunciara e a Declaração Universal dos Direitos do Homem de 1948 indicara.

Como resultado desse fenômeno a ciência jurídica passou a trabalhar uma teoria dos direitos fundamentais que alterou drasticamente a conformação da clássica teoria da constituição. ao ponto de até mesmo substituí-la como eixo dos estudos constitucionais. $O$ constitucionalismo está hoje preocupado em entender a abrangência e os limites dos direitos fundamentais nos sistemas jurídicos e políticos das sociedades contemporâneas e em desenvolver uma dogmática que habilite os juristas a operá-los e torná-los eficazes, e nesse esforço submete claramente a organização do poder estatal aos parâmetros extraídos da teoria dos direitos fundamentais.

Subjacente à guinada do constitucionalismo para a tutela dos direitos fundamentais está uma filosofia do sujeito neo-humanista, que radica na dignidade imanente do ser humano a construção das instituições sociais e submete a existência e o funcionamento do Estado à garantia de uma vida digna a todos os seres humanos, conceito complexo cujo núcleo parece residir na posse das liberdades básicas e na proteção contra a opressão física e moral e as carências materiais. O princípio da dignidade humana constituiu-se em uma espécie de aleph borgiano dos direitos fundamentais, onde se encontra a fonte de todos esses direitos e a origem da própria idéia de justiça que permeia o constitucionalismo contemporâneo, portanto da filosofia e da teoria dos direitos fundamentais.

1 Conquanto extensa a literatura sobre a evolução do constitucionalismo no sentido do texto, foram referenciais na produção do ensaio as obras de MATTEUCCI, Nicola, Organización del poder y liberdad, Editorial Trotta, Madri.1998, KRIELE, Martin, Introducción a la Teoria del Estado, Editora Depalma, Buenos Aires, 1980, e ZAGREBELSKI, Gustavo, El Derecho Dúctil, Editoral Trotta, Madri. 1999. 
O errático constitucionalismo brasileiro alinhou-se tardiamente a esse movimento de ancoragem das constituições nos direitos fundamentais a partir da Carta Magna de $1988^{2}$. A recepção do cânone da dignidade da pessoa humana como um dos fundamentos políticos do Estado brasileiro e o extenso e complexo catálogo de direitos fundamentais, inseridos em um sistema aberto de princípios e regras jurídi$\cos$, que atende a um amplo leque de interesses sociais e individuais, demonstra que o advento constitucional de 1988 representou um notável ponto de mutação na história do constitucionalismo brasileiro.

Se a adesão a este modelo centrado na tutela dos direitos humanos tardou e foi concebida em um período de indefinição política e econômica no Brasil e no mundo, não se poderá acusar a Constituição Federal de 1988 de significar um produto final ou um fruto de um pensamento político e jurídico consolidado, incapaz de renovar a sociedade e atuar como um agente transformador. Ao contrário, a Lei Fundamental de 1988 está fundada em uma idéia de Estado construtivista, comprometido com a criação de uma sociedade emancipada e igualitária e com um Direito inteiramente afinado com o vigente constitucionalismo dos direitos fundamentais do homem.

Entretanto, o ingresso do constitucionalismo brasileiro nesse modelo jurídico vem despertado um interesse ainda tímido da doutrina, em comparação com o panorama europeu e norte-americano. Os estudos da doutrina constitucional brasileira sobre direitos fundamentais são escassos e ressentem-se de perspectivas conservadoras, quando não reacionárias, portadoras daquela que Luiz Roberto Barroso acidamente denominou de uma das patologias crônicas da hermenêutica constitucional brasileira, "que é a interpretação retrospectiva, pela qual se procura interpretar o novo de maneira a que ele não inove nada, mas, ao revés, fique tão parecido quanto possivel com o antigo" 3 , e que não ficaria demasiado chamar de "Síndrome de Lampedusa".

Sinteticamente poder-se-ia apontar três grandes frentes de estudo desse constitucionalismo centrado na teoria dos direitos fundamentais: a fundamentação, a positivação e a eficácia dos direitos fundamentais do homem. É bem conhecida a afirmação de Norberto Bobbio, feita já na década de 60 do século passado, de que "o problema fundamental em relação aos direitos do homem, hoje, não é tanto o de justificá-los, mas o de protegê-los". Para Bobbio, desde que a maior parte dos governos existentes proclamou a Declaração Universal dos Direitos do Homem, demonstrando haver consenso a respeito de quais os direitos humanos que devem ser protegidos na sua relação com o Estado, a questão dos fundamentos perdeu grande parte do seu interesse ${ }^{4}$. O problema nuclear dos direitos do homem seria, então, a sua proteção, vale dizer, a eficácia dos direitos fundamentais.

2 Para um breve mas interessante panorama da renovada influência global do Rule of Law, sobretudo nos países em desenvolvimento, nas últimas décadas, CAROTHERS, Thomas, The Rule of Law Revival, Foreign Affairs, v. 77/2, Março/Abril 1998, p. 95.

3 BARROSO, Luiz Roberto, Interpretação e Aplicação da Constituição, Editora Saraiva, p. 67.

4 BOBBIO, Norberto, A Era dos Direitos, Ed. Campus, pp. 23/24. 
A afirmação de Bobbio sofreu um parcial mas consistente revés nas duas últimas décadas do século XX, quando doutrinas políticas e econômicas neoliberais tornaram-se hegemônicas e passaram a questionar a validade da garantia dos direitos sociais e econômicos, pregando a redução e até a eliminação desses direitos. Ressurgiu, portanto, um problema de fundamentação dos direitos humanos, restrito, é verdade, à justificação da pertinência política e da fundamentalidade dos direitos sociais.

Sem embargo, é inegável que o problema central da teoria dos direitos fundamentais é a sua proteção efetiva, o que é especialmente verdadeiro em relação aos direitos sociais, econômicos e culturais. Curiosamente, a doutrina constitucional, que antes do assalto neoliberal buscava superar o pessimismo com a eficácia jurídica dos direitos sociais através de importantes contribuições dogmáticas à sua proteção judicial, retomou e aprofundou esse pessimismo na ressaca da onda neoliberal, contrastando com a surgimento de soluções criativas e corajosas nas cortes judiciais, isoladas mas crescentes, visando a conferir eficácia jurídica a essa categoria de direitos. Talvez pelo seu caráter insular, esses precedentes não têm mobilizado a doutrina a estudá-los e a confrontar a lógica que os dirige com as estruturas conceituais dominantes no plano teórico. Se o fizesse, descobriria que tais estruturas teóricas representam hoje os grandes obstáculos na luta pela eficácia da Constituição no plano da justiça social.

Portanto, a eficácia dos direitos sociais é ainda, e agora renovadamente, a questão mais urgente e dramática da teoria dos direitos fundamentais. $O$ foco deste estudo está justamente nesse problema. O seu eixo está na tentativa de conciliar a tutela judicial dos direitos fundamentais sociais com o princípio democrático, conjugando a legitimidade que os direitos recebem da sua fonte constitucional com a legitimidade que a idéia democrática empresta aos procedimentos abertos à discussão pública. Como se verá na terceira e na quarta parte, a influência da teoria discursiva do direito foi preponderante na composição da proposta que denominei de concepção pragmática e dinâmica das normas constitucionais definidoras de direitos sociais.

As reflexões que se seguem não são, é claro, exaustivas; ao contrário, vários dos seus aspectos decisivos deliberadamente não foram aprofundados e, às vezes, sequer enfrentados, sobretudo para evitar uma ampliação indesejável do ensaio. Pretendo apenas tê-las exposto com clareza suficiente para ser compreendido e, com sorte, suscitar o debate sobre as idéias básicas contidas na proposta.

\section{I- Classificação dos direitos fundamentais}

O estudo da eficácia das normas constitucionais de direitos fundamentais sociais demanda um exame prévio das classificações dos direitos fundamentais sobre as quais tem a doutrina constitucional brasileira e internacional trabalhado, a fim de contextualizar os direitos sociais no quadro geral da teoria dos direitos fundamentais e melhor compreender a estrutura e a função que exercem em um sistema jurídico.

A difusão da literatura sobre direitos fundamentais provocou, como não poderia ser diferente, o surgimento de diversas classificações com maior ou menor grau de 
semelhança entre si, ora preponderando um aspecto ora outro, conforme o enfoque e a linha de pesquisa adotados. Mas parece possível fazer convergir as classificações a três perspectivas básicas dos direitos fundamentais, no âmbito dos estudos jusconstitucionais: as classificações dimensionais, as classificações dogmáticas e as classificações de direito positivo.

\section{Classificação dimensional}

As classificações dimensionais extraem sua fonte material da evolução histórica do reconhecimento de direitos fundamentais, mas buscam superar a impropriedade que a taxionomia historicista impõe à visão adequada do fenômeno, ao compartimentar espécies de direitos em conformidade com a ordem cronológica que a espécie foi reconhecida no curso da história. Com efeito, as classificações históricas valeram-se da categoria de gerações de direitos para explicar a evolução dos direitos fundamentais, concepção que poderá ser útil à historiografia do constitucionalismo, mas que passa a errada impressão de que uma geração de direitos substitui ou sucede a anterior, quando todo o fenômeno dos direitos fundamentais na história consiste num permanente acrescentar novas espécies jusfundamentais às já reconhecidas. A história dos direitos fundamentais é uma história de densificação e ampliação, não de sucessão.

Por isso a doutrina corretamente convergiu para a categoria de dimensões de direitos fundamentais, que mantém sua fundação na pesquisa da evolução histórica mas a supera, ao atribuir a cada espécie materialmente aproximada de direitos não o liame cronológico, mas a pertença a uma mesma dimensão de conteúdo 5 .

A primeira é a dimensão dos direitos liberais, que esteve na origem no movimento constitucionalista moderno e foi o grande estandarte do longo e tortuoso processo de emancipação do homem que se inicia com as guerras de religião do século XVI na Europa. $\mathrm{O}$ acento tônico dos direitos liberais é a proteção da liberdade humana em suas diversas manifestações, uma liberdade que protege inicialmente e desde então contra o poder do Estado, o algoz recorrente e incorrigível da liberdade, mas que depois estende sua pretensão de tutela a toda forma de opressão, seja ela política seja econômica, venha do Estado venha doutras fontes de poder vertical.

Agrega-se à defesa da liberdade a tutela da igualdade formal, no princípio de modo tímido, seletivo e elitista, mas no passo da construção e consolidação dos regimes democráticos uma igualdade completa e universal, que tenta equilibrar a eliminação de todas as formas de discriminação experimentadas pela civilização humana, de raça, cor, sexo, etnia, opção religiosa, orientação sexual, com o respeito pelo pluralismo e pela diversidade inerente à espécie e à cultura humanas. Mas apesar de acentuar a igualdade, é ainda dentro do quadro do liberalismo que se movem esses direitos, os direitos de liberdade e os direitos de igualdade, em que a preocu-

5 Ver SARLET, Ingo Wolfgang, A Eficácia dos Direitos Fundamentais, Livraria do Advogado, 1998 , p. 46 e ss. 
pação central está em garantir ao homem universal, pensado como categoria (relativamente) abstrata, a proteção de uma esfera de autodeterminação (legitimamente) intransponível pelo poder político, pelo poder econômico ou pela força bruta.

A segunda dimensão fere os direitos que são o objeto deste estudo. É a dimensão dos direitos sociais, que deriva de fatores diversos e complexos típicos da história das sociedades liberais capitalistas, freqüentemente apontada como produto exclusivo das disfunções do capitalismo, seja por decorrer de pressões dos setores prejudicados pelo sistema econômico a partir do século XIX e sobretudo na primeira metade do século XX, seja por representar uma concessão estratégica do capital ao trabalho a fim de preservar o regime contra revoluções comunistas ou socialistas. Essa dimensão, todavia, encerra a percepção da extrema relevância ou da fundamentalidade de determinadas necessidades humanas existentes não apenas em sistemas capitalistas industriais, como em todo e qualquer regime econômico conhecido na história, daí porque a proteção de direitos sociais não seria de modo algum estranha, por exemplo, ao feudalismo e ao mercantilismo.

A dimensão dos direitos sociais altera a perspectiva de oposição entre indivíduo e Estado, ou entre sociedade e Estado, típica dos direitos liberais. Naqueles, o indivíduo e a sociedade postulam do Estado a proteção contra a opressão econômica, e por isso a tutela do trabalhador é a gênese histórica dos direitos sociais, e que os liberte da necessidade, através do provimento de serviços públicos que propiciem uma existência digna, como a educação, a saúde, a cultura, a assistência aos desamparados e incapacitados. Que produza, enfim, bem-estar material ao indivíduo e à sociedade.

Com os direitos sociais, no quadro de uma sociedade liberal, não se busca uma igualdade material radical, típica do ideal comunista, mas uma igualdade material relativa, que oportunize a máxima isonomia de recursos ${ }^{6}$ possível e reduza efetivamente a desigualdade econômica e cultural entre os indivíduos a um nível compatível com a dignidade humana. Há uma efetiva superação da igualdade formal do liberalismo burguês em ordem a aproximar-se da igualdade econômica e social, mas sem renunciar à garantia das liberdades, e antes antepondo-a como pressuposto político e jurídico da justiça social.

Por fim, aquela que denominarei de dimensão dos direitos fundamentais comunitários, composta de direitos que não se referem ao indivíduo abstrato ou ao indivíduo em suas relações sociais e econômicas, e sim a interesses concernentes à vida comunitária na sociedade e que, por terem uma autonomia conceitual, não se confundem com os interesses isolados ou agrupados dos indivíduos. Inserem-se nesta dimensão o direito à proteção ambiental, a faceta coletiva da tutela ao consumidor, o direito à informação, o direito à autodeterminação e ao desenvolvimento econômico. É a mais recente das dimensões de direitos fundamentais, mas representa um

6 Em Sovereign Virtue, The Theory and Practice of Equality, Harvard University Press, 2000, Ronald Dworkin sustenta a preferência pela igualdade de recursos, e não pela igualdade de bemestar, como a alternativa teórica e praticamente adequada a uma concepção democrática de igualdade, na linha do liberalismo igualitário de John Rawls, com a qual está afinado. 
avanço marcante do substrato individualista que caracterizou o Direito moderno, na medida em que permite a proteção normativa e judicial de bens e interesses transindividuais, que pertencem ao conjunto da sociedade indistintamente, e que portanto são titularizados simultaneamente por cada um e por todos os indivíduos de uma comunidade.

É comum inserir nessa dimensão direitos caracterizados pelos valores da solidariedade e da fraternidade, e em realidade essa dimensão sofre forte influência axiológica desses princípios; entretanto, eles estão igualmente presentes nas fontes históricas dos direitos sociais, em relação aos quais o apelo à idéia de igualdade material entre os indivíduos e mútua colaboração para atingir a justiça social exerceu um papel motivador decisivo para a sua instituição. Assim, não parece adequado atribuir aos direitos da terceira dimensão um monopólio da idéia de solidariedade, que sempre exerceu e deve mesmo continuar exercendo um papel protagonista na fundamentação dos direitos sociais.

\section{Classificação dogmática}

A segunda classificação de que nos ocuparemos é a dogmática, e sua denominação encontra origem no esforço dos teóricos dos direitos fundamentais para fundar uma classificação que permita exclusivamente ao jurista compreender as diferenças presentes na estrutura e na função jurídicas dos direitos fundamentais. As classificações dogmáticas, significativamente uniformes entre si, recorrem a um critério operacional básico a partir do qual desenham o sistema proposto. Conquanto nem sempre fique claro, o critério operacional preferido, e a meu ver o mais adequado sob o enfoque das classificações dogmáticas, consiste no objeto da relação entre $o$ titular do direito fundamental $e$ o seu destinatário, o sujeito passivo da relação jurídica jusfundamental.

A divisão que tenho por dogmaticamente adequada distingue direitos de defesa, direitos à prestação e direitos de participação, o que implica já uma tomada de posição pessoal, porque esse não é o sistema dogmático preponderante na doutrina, e portanto exige uma justificação, a ser feita após a apresentação analítica da classificação.

Os direitos de defesa caracterizam-se por expressarem posições jurídicas subjetivas que exigem a omissão do Estado em relação a uma esfera de autonomia individual composta por um conjunto de bens considerados imprescindíveis para a realização ótima da personalidade humana. São, pois, direitos contra o Estado, em que há uma contraposição imanente entre o indivíduo titular do direito e o Estado seu destinatário, ao qual se impõe abstenção de atuação a fim de proteger esse espaço privado da subjetividade individual. Por conseguinte, o objeto da relação jusfundamental nos direitos de defesa é uma ação negativa do Estado em relação aos seus titulares.

Os direitos de defesa têm uma dupla funcionalidade. Por um lado, assumem típica função de direito subjetivo, atributiva de um poder de exigir do sujeito passivo da relação jurídica jusfundamental a conduta omissiva prevista na norma-fonte do 
direito. De outro, exercem a função de norma de competência negativa para o Estado. Como assinalam Pieroth e Schlink, os direitos fundamentais "têm uma função jurídico-objetiva, através da qual o espaço de ação e de decisão do Estado é limitado. O Estado não pode fazer uso de suas competências legislativas, administrativas ou judiciais, exceto dentro dos limites admitidos pelos direitos fundamentais. Eles são os limites ou a negação das competências do Estado, e, portanto, normas de competência negativa" ".

Os direitos fundamentais a prestações têm como objeto o poder de exigir do Estado o provimento de condições materiais, serviços e instituições capazes de suprir bens e interesses pertinentes à situação econômica, social e cultural dos indivíduos. A relação entre os sujeitos da relação jusfundamental é, neste caso, diametralmente oposta àquela dos direitos de defesa. Lá o Estado tem um dever de não-ingerência em relação à esfera individual; aqui, o Estado tem um dever de agir em benefício do indivíduo, através do provimento de prestações materiais (acesso à educação, assistência médica, institutos de previdência social) ou jurídicas (normas de proteção ao trabalhador ou de regulação dos contratos que afetem os direitos de habitação). Reside aqui, como é evidente, a quase totalidade dos denominados direitos fundamentais sociais.

Robert Alexy define os direitos a prestação em sentido estrito como "os direitos do indivíduo frente ao Estado a algo que, se o individuo possuísse meios financeiros suficientes, poderia obter também de particulares" 8 . Esse expressivo conceito refere-se exclusivamente ao que considera os direitos de prestação stricto sensu, espécie que engloba os direitos a prestação material devidos pelo Estado ao indivíduo para a garantia do seu bem-estar social básico. A despeito da restrição do conceito, que não abrange importantes setores dos direitos a prestação (como grande parte dos direitos à prestação de proteção jurídica nas relações de trabalho), ele expressa com agudeza o caráter contingencial dos direitos sociais, que devem sua existência, extensão e intensidade ao grau de escassez objetiva da economia e à capacidade financeira dos atores sociais ${ }^{9}$.

7 PIEROTH/SCHLINK, Grundrechte, Staatrecht II, Ed. C. F. Müller, 14* edição, p. 20. O texto original é o seguinte: "Eine objektiv-rechtliche Funktion haben die Grundrechte zum einem dadurch, dass sie den Handlungs - und Entscheidungsspielraum des Staats begrenzen. Von seinen Gesetzgebungs - , Verwaltungsund Rechtsprechungskompetenzen kann der Staat keinem beliebigen, sondern nur den Gebrauch machen, den die Grundrechte zulassen. Sie sind Grenze oder Negation seiner Kompetenzen und insofern negative Kompetenznormen". Os autores citados referem-se a essa função de competência negativa em relação aos direitos fundamentais em geral, sem atribuí-los exclusivamente aos direitos de defesa, como parece mais correto e como fazem, sem contudo justificar, GOMES CANOTILHO, J. J., em Direito Constitucional, Ed. Almedina, 5a edição, p. 552, e SARLET, Ingo Wolfgang, Eficácia dos Direitos Fundamentais, Ed. Livraria dos Advogados, p. 168. Os direitos à prestação não exercem esse papel, e sim o de competência positiva do Estado.

8 ALEXY, Robert, Teoria de los Derechos Fundamentales, Centro de Estudios Constitucionales, Madrid, p. 482.

9 Não parece correta, entretanto, a concepção instrumental dos direitos sociais em relação aos direitos liberais, enquanto categorias do domínio jurídico, que parte da doutrina sustenta. Segundo 
A terceira e última espécie, no quadro da classificação dogmática, é a dos direitos fundamentais de participação, que atribuem aos seus titulares posições jurídicas subjetivas de participação na vida política do Estado. Eles manifestam-se principalmente através dos direitos políticos: do direito ao voto, que permite participar na escolha dos representantes parlamentares e executivos, bem como expressar opções políticas em assuntos de interesse público submetidos a plebiscito ou referendo; do direito de candidatar-se e exercer cargos eletivos; ou, ainda, o direito de propor projeto de lei de iniciativa popular. Mas manifestam-se também em direitos que estão além dos direitos políticos stricto sensu, como o direito de acesso a cargos públicos, o direito de petição aos órgãos governamentais, de propor ação popular.

A doutrina divide-se quanto à autonomia científica dos direitos de participação em relação às outras duas categorias jusfundamentais, os direitos de defesa e à prestação. Robert Alexy, na sua proposta taxionômica, insere-os em uma subdivisão da classe dos direitos à prestação, os direitos à organização e ao procedimento, porque o objeto destes direitos estaria em atribuir aos indivíduos o poder jurídico de exigir do Estado a criação de normas jurídicas e institutos que lhe permitam o efetivo gozo do direito de participar na formação da vontade estatal ${ }^{10}$. Ingo Wolfgang Sarlet encarta-os entre os direitos de defesa, porque considera seja essa a função preponderante daquela espécie de direitos fundamentais, embora ressalve que alguns de seus aspectos podem ser considerados atinentes aos direitos a prestações estatais ${ }^{11}$.

Não sigo essa orientação. Como disse, o critério operacional distintivo que empregamos para diferençar as espécies dogmáticas jusfundamentais é o objeto da relação jurídica entre o titular e o destinatário da norma de direito fundamental. Os direitos fundamentais à participação não visam a defender o indivíduo ou o cidadão de ingerências indevidas do Estado em uma esfera livre de autonomia privada, tampouco limitam-se a exigir do Estado a criação de normas e a organização de procedimentos e instituições que permitam o exercício da participação política.

esta acepção, os direitos sociais tutelam interesses cuja razão final é a garantia do gozo das liberdades e igualdades fundamentais. Ainda que se considere que os direitos gerais de liberdade e de igualdade constituem os bens primários em um esquema de hierarquização axiológica no plano constitucional (no sentido de Teoria da Justiça de John Rawls, por exemplo), os direitos sociais visam a assegurar um certo grau básico - e não mínimo - de condições materiais e de segurança econômica aos indivíduos mediante a tutela de bens $e$ interesses que, no plano do sistema jurídico, adquirem autonomia, e que podem ser reinvindicados - e já o foram muitas vezes na história - mesmo em sistemas políticos que sacrifiquem total ou parcialmente a liberdade ou a isonomia.

10 ALEXY, Robert, Teoria de los Derechos Fundamentales, p. 481.

11 SARLET, Ingo Wolfgang, Eficácia dos Direitos Fundamentais, pp. 174/178, onde o autor afirma arrimar-se na orientação de Konrad Hesse. Com efeito, conquanto não seja claro a respeito, para HESSE (Grundzüge des Verfassungsrechts der Bundesrepublick Deutschland, Editora C. F. Müller, $20^{a}$ ed., p. 131) os direitos fundamentais regulam o status do cidadão, não apenas para protegê-lo do Estado em sua esfera de autonomia privada, mas também para cooperar nos assuntos da coletividade, atuação que reconduz a uma categoria especial de liberdade, consistente nos direitos de colaboração (Mitwirkungsrechte), dentre os quais arrola a participação na formação da vontade política, posição que parece conciliar-se com a defendida por Ingo Sarlet. 
É certo que os direitos de participação pressupõem a liberdade positiva de atuar na esfera da vida pública, na velha acepção de liberdade dos antigos celebrizada por Benjamin Constant, e também demandam a existência de normas e instituições governamentais que viabilizem materialmente o seu exercício. Mas esses são aspectos por assim dizer acessórios na estrutura da categoria, cujo acento tônico está no poder jurídico de agir na esfera pública, tomando parte ativa na formação da vontade estatal e exercendo funções públicas. A importância central que essa posição jurídica subjetiva ocupa no cenário de um Estado Democrático de Direito permite-lhe adquirir autonomia científica em relação às demais classes dogmáticas de direitos fundamentais $^{12}$.

A esse propósito, convém examinar dois pontos que ferem a pureza das classificações dogmáticas que seguem, com modificações e especificações, o modelo acima descrito. $\mathrm{O}$ primeiro consiste na constatação de que muitos direitos fundamentais que compartilham similitudes relevantes entre si, por pertencerem verbi gratia à dimensão dos direitos sociais, não se adequam necessariamente à mesma categoria dogmática. Esse problema é particularmente visível nos direitos à prestação, classe composta basicamente pelos direitos fundamentais sociais. Entretanto, alguns direitos sociais, inclusive inscritos como tais no texto da Constituição Federal, não demandam uma prestação positiva do Estado, e sim a sua abstenção, como ocorre nos direitos à associação sindical, à greve e contra discriminações nas relações de trabalho, razão por que pertencem não à classe dos direitos à prestação, tal como seus congêneres dimensionais, mas à dos direitos de defesa ${ }^{13}$.

O segundo ponto concerne à complexidade estrutural e funcional dos direitos fundamentais, que os torna rebeldes a uma acomodação conceitual tout court e definitiva nas categorias dogmáticas propostas na doutrina. O estudo da estrutura e da função dos direitos fundamentais demonstra que eles, em regra, não estão constituídos apenas por pretensões, expectativas e interesses próprios de sua classe, ainda que se possa recolher em cada um deles uma pretensão predominante efetivamente adequada à respectiva categoria. Em síntese, os direitos fundamentais não possuem a homogeneidade de conteúdo pressuposta pelos esquemas conceituais das classificações dogmáticas; bem ao contrário, caracterizam-se por uma heterogeneidade complexa de direitos, pretensões, expectativas e interesses que impedem uma inserção em bloco e sem reservas nas classes já delineadas.

12 Compartilham da orientaçāo defendida no texto VIEIRA DE ANDRADE, J. C.. Os Direitos Fundamentais na Constituição Portuguesa de 1976, Ed. Almedina, p. 192, e FARIAS, Edílsom Pereira de, Colisão de Direitos, Editora Sérgio Sabris, p. 92.

13 Para um exame detalhado do problema. ver SARLET, Ingo Wolfgang, em Os Direitos Fundamentais Sociais da Constituição de 1988, publicado em Os Direitos Sociais em Tempos de Crise, Editora Livraria dos Advogados, p. 146, onde destaca que a reforma na Constituição Portuguesa de 1976, realizada em 1982, atenta para essa incongruência, deslocou esses direitos sociais de defesa, notadamente as liberdades e garantias dos trabalhadores, para o título II da Constituição, onde estão catalogados os direitos de defesa. Essa refundição e a análise de sua motivação, nos termos examinados no ensaio, é também salientada por MIRANDA, Jorge, em Os Direitos Fundamentais - sua Dimensão Individual e Social, em Cadernos de Direito Constitucional e Ciência Política, Editora Revista dos Tribunais, vol. 1, 1992, p. 198 e ss. 
Assim, os direitos de defesa da liberdade não podem ser satisfeitos com a mera abstenção do Estado, porque a sua efetiva satisfação exige que o Estado proporcione condições de segurança mediante prestações estatais positivas, inclusive normativas, instituindo, por exemplo, normas de direito penal em ordem a reforçar a proteção das liberdades básicas ${ }^{14}$.

Os direitos à prestação podem, igualmente, assumir uma feição defensiva. Isso ocorre em face do próprio conteúdo normativo do direito fundamental, como a proibição de discriminação no acesso e permanência na escola e a gratuidade do ensino público no direito à educação (art. 206, IV), que exigem abstenção estatal no âmbito de provimento de um típico direito à prestação. Pode também ocorrer na fase executiva dos direitos sociais à prestação, momento em que o Estado deve abster-se de praticar atentados à igualdade no provimento de benefícios e serviços públicos. E pode, por fim, suceder-se quando direitos sociais à prestação foram já disciplinados no plano infraconstitucional, quando se pode vislumbrar um direito à abstenção imposto ao Estado, de modo a proibir a redução do espectro de segurança social definido na legislação prestacional, enriquecendo os direitos sociais tutelados no âmbito infraconstitucional com uma dimensão defensiva ${ }^{15}$.

$\mathrm{E}$, como antes mencionado, o mesmo fenômeno caracteriza os direitos à participação, que, de um lado, inegavelmente inserem-se entre os direitos liberais, e, de outro, realmente demandam do Estado o provimento de prestações normativas e a organização de instituições e procedimentos que operacionalizem o exercício dos direitos políticos. Ainda assim, o fio condutor, a nota marcante do direito reside no poder deferido ao cidadão de participar, através do exercício pessoal de uma ação positiva, da condução da coisa pública, e por isso a afirmação da autonomia dos direitos à participação em relação aos direitos de defesa e a prestações estatais.

Essa dificuldade conceitual que a heterogeneidade da estrutura e das funções dos direitos fundamentais impõe às classificações dogmáticas pode ser superada recorrendo a uma divisão dos direitos fundamentais em duas concepções semânticas: os direitos fundamentais podem ser concebidos em sentido estrito ou em sentido amplo.

No sentido estrito, o direito fundamental restringe-se à prestação jurídica principal prevista na norma constitucional atributiva do direito, ou seja, ao seu conteúdo nuclear, aquele que fornece a característica mais saliente e distintiva do direito. Serão direitos de defesa aqueles cujo objeto nuclear for a exigência de uma omissão do Estado em face de uma esfera de autonomia pessoal e o respeito às igualdades básicas. Serão direitos à prestação aqueles cujo objeto nuclear estiver no provimento de prestações positivas do Estado em favor dos indivíduos e da sociedade. E constituirse-ão direitos à participação aqueles centralizados pelo poder concedido ao cidadão de participar da vida pública do Estado.

14 Ver MIRANDA, Jorge, Os Direitos Fundamentais - sua Dimensão Individual e Social, $C D C C P$, vol. 1, 1992, pp. 201 e ss., e SARLET, Ingo Wolfgang, A Eficácia dos Direitos Fundamentais Sociais na Constituição de 1988, Os Direitos Sociais em Tempos de Crise, pp. 148/49.

15 SARLET, Ingo Wolfgang, A Eficácia dos Direitos Fundamentais, p. 364 e ss. 
Em sentido amplo, os direitos fundamentais serão compostos não apenas pela prestação jurídica principal, mas pelas demais prestações acessórias ao direito, a título de direitos, pretensões, expectativas e interesses, as quais podem assumir formas de direitos de defesa, a prestações estatais ou à participação, conforme a estrutura e a função típicas do direito fundamental respectivo. Assim, conquanto o direito à educação tenha como conteúdo nuclear a demanda de uma prestação estatal, e portanto em sentido estrito pode ser descrito simplesmente como direito fundamental à prestação, em sentido amplo está composto não apenas da prestação principal que o caracteriza e define sua posição taxionômica, mas também de direitos acessórios de defesa contra a intervenção estatal e até, eventualmente, de participação, como se pode vislumbrar nos casos em que o estudante pode participar da escolha dos dirigentes dos estabelecimentos de ensino.

Passa-se de um conceito simples de direito fundamental, limitado ao objeto básico da relação jurídica jusfundamental, que conforme a classificação dogmática será de defesa, de prestações estatais e de participação, para um conceito complexo, composto por outros elementos juridicamente autônomos mas ligados pelo interesse nuclear do direito fundamental, perfazendo uma totalidade com um conteúdo heterogêneo mas harmônico.

Essa dicotomia foi explorada por Robert Alexy, em sua Teoria dos Direitos Fundamentais ${ }^{16}$, e, a rigor, nada tem de novidade. Trata-se da mera transposição de uma antiga distinção que a doutrina civilista alemã utiliza para conceituar a relação obrigacional, que teve em Karl Larenz um de seus primeiros e mais influentes téoricos, e que hoje é amplamente reconhecida nos estudos de Direito Civil doutros países, inclusive no Brasil ${ }^{17}$.

16 ALEXY, Robert, Teoria de los Derechos Fundamentales, pp. 240 e ss.

17 Há uma farta bibliografia sobre o tema, desde a obra básica de LARENZ, Lehrbuch des Schuldrechts. Na doutrina germânica, WIEACKER, Franz arrola essa distinção como uma das mais significativas conquistas da dogmática jusprivatista moderna, em História do Direito Privado Moderno, Fundação Calouste Gulbelkian, p. 597. Em Portugal, a divisão é aceita, por exemplo, por ALMEIDA COSTA, Mário Júlio de, Direito das Obrigações, Coimbra Editora, $4^{2}$ edição, pp. 45 e ss., MOTA PINTO, Carlos Alberto da, Teoria Geral do Direito Civil, Coimbra Editora, pp. 178 e ss. (que aplica a dicotomia às relações jurídicas em geral), MENEZES CORDEIRO, Antônio, $D a$ Boa Fé no Direito Civil, Editora Almedina, pp. 586 e ss. No Brasil, foi introduzida por COUTO E SILVA, Clóvis em A Obrigação como um Processo, Editor José Bushatski, obra escrita na década de 60 , na qual já na introdução situa histórica e dogmaticamente a concepção dualista e assinala: "a relaçāo obrigacional pode ser entendida em sentido amplo ou em sentido estrito. "Lato sensu" abrange todos os direitos, inclusive os formativos, pretensões e açōes, deveres (principais $e$ secundários dependentes e independentes), obrigações, exceções, e ainda posições jurídicas. "Stricto sensu" dever-se-á defini-la tomando em consideração os elementos que compõem o crédito e o débito, como faziam os juristas romanos", ob. cit., p. 8. Sobre essa obra e o conceito complexo de obrigação, escrevi em O Conceito de Obrigação como um Processo, Revista do Ministério Público, n. 30, 1994, p. 206. Mais recentemente, a erudita tese de doutoramento de MARTINS-COSTA, Judith, A Boa Fé no Direito Privado, Editora Revista dos Tribunais, pp. 383 e ss. 


\section{Classificação positiva}

A terceira classificação a ser abordada é tecida a partir da técnica adotada pelo constituinte na elaboração do catálogo de direitos fundamentais da Constituição Federal de 1988, e por isso pode ser denominada de classificação positiva ou de direito positivo dos direitos fundamentais. Não é tarefa fácil desvendar o critério operacional básico utilizado pelo legislador constituinte na confecção do catálogo, em virtude das inevitáveis incongruências internas de uma classificação feita por processo legislativo, para o qual concorrem um elevado grau de arbítrio e a falta de compromisso com as idéias de unidade e coerência que marcam o esforço taxionômico desenvolvido ao amparo da racionalidade científica.

Mas é possível descobrir, no exame da técnica utilizada pelo constituinte, uma lógica interna que se sujeita a uma operação classificatória, e a classificação proposta por José Afonso da Silva, referenciada na natureza jurídica do bem protegido pela norma jusfundamental, parece apreender corretamente a lógica do texto constitucional, desenhando a seguinte divisão: a) direitos fundamentais do homem-indivíduo, que reconhecem uma esfera de autonomia privada aos indivíduos em face do Estado e dos demais membros da sociedade política, e que são tradicionalmente identificados como direitos individuais na história do Direito Constitucional brasileiro; b) direitos fundamentais do homem-membro de uma coletividade, definidos na Carta Magna como direitos coletivos e que respondem ao fenômeno da existência de bens e interesses associados à vida comunitária típica das sociedades contemporâneas, tal como se explorou na terceira dimensão da classificação dimensional; c) direitos fundamentais do homem-social, que constituem os direitos assegurados ao indivíduo em suas relações sociais, econômicas e culturais, e que são tratados universalmente sob a categoria de direitos sociais; d) direitos fundamentais do homem-nacional, que definem o estatuto jurídico do vínculo de nacionalidade em relação ao Estado, prevendo seus direitos, garantias, privilégios e faculdades; e) direitos fundamentais do homem-cidadão, que regulam a participação do indivíduo na vida política do Estado brasileiro ${ }^{18}$.

A partir desse esquema compreende-se a divisão presente no próprio texto constitucional e identificada por José Afonso da Silva, que separa os direitos fundamentais em cinco grupos: $1^{\circ}$ ) direitos individuais, previstos principalmente no artigo $5^{\circ}$ da Constituição Federal; $2^{\circ}$ ) direitos coletivos, igualmente no artigo $5^{\circ}$, por exemplo nos incisos XIV (direito à informação) e XXXII (proteção do consumidor), mas também no artigo 225 (direito à proteção do meio ambiente); $3^{\circ}$ ) direitos sociais, tendencialmente acolhidos nos artigos $6^{\circ}$ e $7^{\circ}$, mas também presentes nos artigos 196 (direitos à saúde), 201 e 202 (direitos de previdência social), 203 (direitos de assistência social), 205 (direito à educação), 227 (direitos de proteção à infância e juventude) e 230 (direitos de proteção aos idosos); $4^{\circ}$ ) direitos de nacionalidade, dispostos no artigo 12; e $5^{\circ}$ ) direitos políticos, do artigo 14 ao $17^{19}$.

18 SILVA, José Afonso da, Direito Constitucional Positivo, Editora Revista dos Tribunais, 6* edição, p. 163.

19 SILVA, José Afonso da, obra citada, p. 165. 
A despeito da resistência que a classificação positiva possa provocar em uma hermenêutica científica e purista, é inegável o valor epistemológico da classificação para compreender o sentido de determinadas normas constitucionais alusivas aos direitos fundamentais. Apenas para exemplificar, e sem ingressar na relevante polêmica que se trava a respeito, consideramos decisivo o critério do constituinte para interpretar o alcance da expressão "direitos e garantias individuais" no artigo 60, $\S$ $4^{\circ}$, IV, da Constituição Federal, onde estão instituídos como limites materiais à reforma constitucional ${ }^{20}$.

\section{II - As normas constitucionais quanto à eficácia}

O problema da eficácia jurídica das normas constitucionais tem a idade das constituições escritas e das declarações de direitos. De fato, os debates sobre o tema iniciam com a Constituição norte-americana de 1787 e com a Declaração dos Direitos do Homem e do Cidadão de 1789 , e desde então representam uma das polêmicas mais acesas do Direito Constitucional.

Um esforço de compreensão histórica do problema, contudo, divisará duas ordens temáticas diferentes. A primeira delas é típica do constitucionalismo norteamericano, centrado em uma constituição escrita acentuadamente sintética e genérica, que nasce com a finalidade precípua de organizar o exercício do poder em um Estado repleto de ineditismos político-jurídicos, e portanto de incertezas e indefinições. As características da Constituição norte-americana determinarão uma gramática interna marcada por normas cuja eficácia jurídica era imediata, e outras cuja eficácia jurídica ficara, no texto constitucional, diferida para a elaboração legislativa infraconstitucional. A compreensão dessa dualidade levará a doutrina a conceituar as espécies de norma, no tangente à sua aplicabilidade direta, em self executing e not self executing, expressões largamente difundidas no Direito Constitucional brasileiro desde o século XIX, principalmente por influência de Rui Barbosa, e que ganharão traduções como normas auto-aplicáveis e não auto-aplicáveis, ainda hoje muito utilizadas na jurisprudência, e bastantes em si e não-bastantes em $\mathrm{si}^{21}$.

Uma outra ordem de problemas advirá da polêmica em torno da eficácia jurídica dos direitos do homem incluídos na Declaração dos Direitos do Homem e do Cidadão de 1789 , no preâmbulo das constituições francesas e européias e mesmo naquelas em que os direitos do homem são incorporados no próprio texto constitucional.

20 Neste sentido, COSTA E SILVA, Gustavo Just da, Os Limites da Reforma Constitucional, Editora Renovar, 2000, p. 124, que vê no uso da expressão a intenção do constituinte de vincular esta classe de limite material explícito aos direitos de liberdade definidos no artigo $5^{\circ}$. Em sentido contrário, SARLET. Ingo Wolfgang, A Eficácia dos Direitos Fundamentais, cit., p. 349 e ss., que entende ser inviável derivar da locução "individuais" a restrição dos limites materiais aos direitos e garantias do artigo $5^{\circ}$, já pela necessária titularidade individual de todos os direitos fundamentais, já pelas incoerências internas do próprio sistema constitucional de direitos fundamentais.

21 PONTES DE MIRANDA. Comentários à Constituição de 1946, Editora Max Limonad, 2 a ed., v. I, p. 99 
Discute-se se esses "direitos" compartilham dos atributos inerentes à categoria de direitos subjetivos, desenvolvida no direito privado, ou se se restringem a ideais filosóficos e culturais, a exortações axiológicas endereçadas ao legislador. Discutese, enfim, se esses direitos são jurídicos e se podem beneficiar-se da eficácia atribuída às normas jurídicas pelo instrumento da justiciabilidade.

A doutrina não se ocupa dessa importante distinção. Um problema reside na natureza da construção gramatical das constituições, porque o projeto constitucional é necessariamente limitado em termos normativos. As constituições regulam apenas a organização básica do poder estatal, por complexa que seja a estrutura do aparelho público, e como sua própria concepção político-jurídica de obra seminal do ordenamento jurídico lhe interdita a regulação detalhada da vida social, é inevitável o recurso a preceitos cuja eficácia remeta à posterior atuação complementar do legislador infraconstitucional. Por isso que uma constituição sempre terá, na esfera organizatória, normas auto-aplicáveis e normas não auto-aplicáveis.

Este raciocínio vale a fortiori para as normas constitucionais definidoras de fins e tarefas do Estado, desconhecidas no constitucionalismo dos séculos XVIII e XIX, mas presentes na totalidade das constituições do século XX, em face do advento do Estado social. Conquanto seja possível dispor sobre fins e tarefas estatais mediante normas constitucionais auto-aplicáveis, freqüentemente será necessário recorrer a normas que, para gerarem a eficácia planejada, demandarão a interposição da atuação legislativa infraconstitucional, criando normas específicas, instituições e serviços públicos capazes de satisfazer as condições normativas e materiais necessitadas para a finalidade pretendida. $O$ problema da escolha entre normas auto-aplicáveis e normas não auto-aplicáveis, sejam organizatórias, sejam definidoras de fins e tarefas é, antes de tudo, um problema da tensão entre o projeto constitucional e a técnica constitucional disponível.

São, contudo, diferentes as questões que emergem do exame da eficácia jurídica das normas constitucionais definidoras de direitos fundamentais, que transcendem fatores de técnica constitucional e invadem áreas de conflito ideológico, de ciência política e de teoria constitucional. Conquanto o panorama dos debates jurídicos sobre a temática seja hoje muito mais favorável à eficácia dos direitos fundamentais liberais do que foi nos albores do constitucionalismo moderno, a ponto de raramente negar-se a auto-aplicabilidade desses direitos, e de que muitas constituições insiram preceitos tornando expressamente cogentes as normas que prevêem direitos fundamentais liberais, as clivagens transferiram-se para a eficácia dos direitos sociais, que foram incorporados aos textos constitucionais do século XX.

No embate sobre a auto-aplicabilidade das normas constitucionais definidoras de direitos fundamentais a questão não é, absolutamente, de técnica constitucional. Aqui predominam disputas travadas no âmbito da teoria constitucional e da ciência política, e são fortemente marcadas por posições ideológicas. Discute-se, aqui, as fronteiras entre o jurídico e o político, entre o político e o econômico e entre o jurídico e o econômico, o confronto entre a força normativa da constituição e os fatores reais de poder, a legitimidade democrática do poder judicial, o papel do princípio majoritário na distribuição de direitos fundamentais, o caráter contramajoritário da tutela judicial dos direitos fundamentais. 
Os estudos sobre a eficácia das normas constitucionais não cuidam dessas diferentes perspectivas. As classificações elaboradas quanto à eficácia das normas constitucionais gravitam em um plano meramente conceitual, típico da jurisprudência clássica dos conceitos, caracterizado pela elaboração de um esquema de definições ao qual são subsumidas normas constitucionais sem indagações críticas. A célebre e aguda crítica de Jhering contra a jurisprudência dos conceitos, a quem acusava de fundar o processo de dedução das normas e decisões jurídicas a partir dos conceitos, ao invés de produzir os conceitos jurídicos a partir do estudo das normas jurídicas ${ }^{22}$, é frequientemente adequada ao uso que se faz das teorias da eficácia das normas constitucionais.

De fato, o programa hermenêutico das concepções semânticas é exclusivamente lógico-subsuntivo, porque atribui ao intérprete da norma definidora de direito social - e das normas constitucionais em geral - a investigação da sua natureza tipológica, o exame do fato a ser regulado e a aplicação da eficácia predeterminada no esquema conceitual. À margem da correção interna de qualquer esquema conceitual dessa espécie - como veremos adiante - é evidente que prestam um tributo tardio e já insustentável ao positivismo científico que fundamentou teórica e praticamente a jurisprudência dos conceitos, vinculando o juiz e o intérprete ao quadro conceitual e afastando da atividade judicial e dos estudos jurídicos os interesses sociais, políticos e econômicos que caracterizam a concretização dos direitos sociais ${ }^{23}$.

De qualquer modo, a classificação dicotômica entre normas constitucionais auto-aplicáveis e não auto-aplicáveis exerceu longa hegemonia no Direito Constitucional brasileiro e, ainda hoje, embora tida como cientificamente superada, em face da sua excessiva simplicidade, é freqüentemente utilizada na interpretação constitucional, tanto da doutrina como da jurisprudência, por certo em decorrência da predomínio do positivismo legalista de matriz privatista no cenário jurídico nacional $^{24}$, mesmo no âmbito do Direito Público. Não há dúvida, contudo, que essa simplicidade não responde corretamente ao fenômeno da eficácia das normas existentes nas constituições modernas.

A mais importante insuficiência da doutrina clássica reside na incompreensão de que todas as normas constitucionais são dotadas de eficácia jurídica; o que varia é a capacidade que terá a norma de gerar, a partir do seu conteúdo normativo, a

22 Ver, a respeito, WIEACKER, Franz, A História do Direito Privado Moderno, p. 457.

23 WIEACKER, Franz, ob. cit., p. 502.

24 Ninguém como Sérgio Buarque de Hollanda expressou com mais exatidão o apego da inteligência brasileira às formas de positivismo, em magnífica passagem de Raizes do Brasil: "O prestigio da palavra escrita, da frase lapidar, do pensamento inflexivel, o horror ao vago, ao hesitante, ao fluido, que obrigam à colaboração, ao esforço e, por conseguinte, a certa dependência e mesmo abdicação da personalidade, têm determinado assiduamente nossa formação espiritual. Tudo quanto dispense qualquer trabalho mental aturado e fatigante, as idéias claras, lúcidas, definitivas, que favorecem uma espécie de atonia da inteligência, parecem-nos constituir a verdadeira essência da sabedoria. É possivel compreender o bom sucesso do positivismo entre nós e entre povos parentes do nosso, como o Chile e o México, justamente por esse repouso que permitem ao espírito as definições irresistíveis e imperativas do Sistema de Comte". 
totalidade da carga eficacial potencialmente existente no enunciado. Algumas normas constitucionais possuem todas as condições necessárias para gerar a integralidade da sua carga eficacial, enquanto outras gerarão apenas uma parcela dela, restando alguns efeitos contidos à espera da concretização de fatores metanormativos, como a elaboração de lei ordinária e a criação de um programa governamental.

A mais célebre e influente classificação das normas constitucionais elaboradas no Direito Constitucional brasileiro segue sendo a de José Afonso da Silva, vetusta da década de 60, mas firme em sua estrutura lógica e na aceitação científica. Exposta na obra Aplicabilidade das Normas Constitucionais, ganhou ao longo dos anos amplo acolhimento na doutrina e na jurisprudência brasileiras, a ponto de poder ser hoje considerada a teoria "oficial" da eficácia das normas constitucionais, relegando a um plano secundário e até ao ostracismo diversas outras formulações conceituais da doutrina nacional, sobretudo a dicotomia clássica, cujas deficiências procurou superar. Como se sabe, José Afonso da Silva divide as normas constitucionais, no enfoque quanto à eficácia, em normas de eficácia plena, de eficácia contida e de eficácia limitada ${ }^{25}$.

Não obstante a excelência da elaboração doutrinária mencionada, um dos seus aspectos centrais tem ensejado inúmeras confusões na transposição da formulação doutrinária para a produção jurisprudencial. A disposição do conceito de norma de eficácia contida no centro da classificação tripartite não tem sido bem compreendida, e não raro provoca interpretações precipitadas de normas constitucionais.

Em verdade, normas de eficácia contida são pura e simplesmente normas de eficácia plena e aplicabilidade imediata que, no entanto, podem, dadas suas características imanentes, ter sua eficácia restringida posteriormente pelo legislador ordinário. Não se confundem, portanto, com as normas de eficácia limitada, que desde sua edição não possuem condições normativas de emanar seus efeitos essenciais.

A rigor, essa classificação intermediária é desnecessária, porquanto o atributo de ter sua eficácia potencialmente restringível pelo legislador ordinário é uma característica inerente a grande parte das normas constitucionais de eficácia plena, sobretudo daquelas que regulam direitos, fundamentais ou não, em face do seu caráter

25 Normas de eficácia plena são "aquelas que, desde a entrada em vigor da constituição, produzem, ou têm possibilidade de produzir, todos os efeitos essenciais, relativamente aos interesses, comportamentos e situações, que o legislador constituinte, direta e normativamente, quis regular".

Normas de eficácia contida "são aquelas em que o legislador constituinte regulou suficientemente os interesses relativos a determinada matéria, mas deixou margem à atuação restritiva por parte da competência discricionária do Poder Público, nos termos que a lei estabelecer, ou nos termos de conceitos gerais nelas enunciados".

As normas de eficácia limitada são divididas pelo autor em duas categorias: normas limitadas de princípio institutivo, que são "aquelas através das quais o legislador constituinte traça esquemas gerais de estruturação e atribuição de órgãos, entidades ou institutos, para que o legislador ordinário os estruture em definitivo, mediante lei"; e as normas constitucionais programáticas, que são "aquelas através das quais o constituinte, em vez de regular, direta e imediatamente, determinados interesses, limitou-se a traçar-lhes os princípios para serem cumpridos pelos seus órgãos (legislativos, executivos jurisdicionais e administrativos), como programas das respectivas atividades, visando à realização dos fins sociais do Estado". 
eminentemente principial. Essa espécie de normas pode ter sua eficácia reduzida no âmbito do próprio texto constitucional ou pelo legislador infraconstitucional, a fim de obter um equilibrio entre as posições individuais, ou, se quisermos usar a expressão do Direito Constitucional germânico, com o objetivo de realizar, pela via legislativa, o princípio da concordância prática dos direitos constitucionais.

Com efeito, a classificação de norma de eficácia contida, pretendida, por exemplo, para o princípio da igualdade de gênero, do art. $5^{\circ}$, I, da Constituição Federal, vale-se de um conceito polêmico, e a nosso juízo carente da cientificidade desejada por José Afonso da Silva. Normas de eficácia contida seriam normas de eficácia plena que poderiam ter sua carga de efeitos restringida - contida - pelo legislador ordinário. Mas, como vimos, este é um fenômeno típico das normas definidoras de direitos fundamentais, que outorgam direitos de textura prima facie ampla e abrangente, mas que podem ter sua incidência limitada na fase de concretização, seja pelo conflito com outros direitos fundamentais - que possuem a mesma hierarquia normativa - , seja pela concreção no plano legislativo, operada pelo legislador ordinário no exercício da sua liberdade de conformação legal. Exemplo eloqüente dessa legitimação do Poder Legislativo para limitar normas constitucionais de eficácia plena encontra-se no direito fundamental de propriedade (art. $5^{\circ}, \mathrm{XXII}, \mathrm{CF}$ ), que é amplamente limitado na legislação infraconstitucional, tanto no Código Civil ${ }^{26}$ ou no Código Tributário ${ }^{27}$, quanto mediante normas de Direito Administrativo.

Logo, é preferível adotar, porque perfeitamente suficiente, a classificação de Meirelles Teixeira ${ }^{28}$, que divide as normas constitucionais em normas de eficácia plena e normas de eficácia limitada, divididas estas em normas de legislação e normas programáticas $^{29}$. A diferença básica entre as duas espécies reside na capacidade de gerar ou não, modo autônomo e sem a necessidade da interpositio legislatoris, os efeitos essenciais previstos quando da produção da norma. Neste contexto, as normas de eficácia contida seriam mera subclassificação das normas de eficácia plena, e obteriam maior precisão se renomeadas para normas de eficácia restringível. Assim, se quisermos aperfeiçoar a classificação singela de Meirelles Teixeira, incorporando nela a distinção subjacente ao conceito de norma de eficácia contida, elaborado por José Afonso da Silva, obteríamos a seguinte classificação:

$\left.1^{\circ}\right)$ normas de eficácia plena, subdivididas em normas de eficácia plena irrestrita, e normas de eficácia plena contivel, ou restringivel (pelo legislador infraconstitucional); e $2^{\circ}$ ) normas de eficácia limitada, subdividida em normas de legislação e normas programáticas.

26 Ver, a título de exemplo, o art. 554 do Código Civil, que prevê restrição ao direito de propriedade quando o proprietário dele fizer "uso nocivo"; ou ainda, a restrição consistente na passagem forçada, prevista no art. 559 do Código Civil.

27 Ver o art. 78 do Código Tributário Nacional, que define o poder de polícia do Estado, que autoriza limitar o uso e o gozo do proprietário para fins de interesse público.

28 TEIXEIRA, J. H. Meirelles, Curso de Direito Constitucional, Editora Forense Universitária, pp. 316 e ss.

29 Para uma crítica à teoria de José Afonso da Silva e uma idêntica opção pela classificação simplificada e mais exata de Meirelles Teixeira, ver SARLET, Ingo Wolfgang, Os Direitos Fundamentais e sua Eficácia na Ordem Constitucional, Revista AJURIS, n. 75. v. II, p. 371. 
Essa a razão da preferência científica pela classificação mais simples, mas mais exata, de Meirelles Teixeira, acrescida das subclassses de normas de eficácia plena. A exposição demonstra a possibilidade de organizar uma teoria dogmaticamente adequada das normas constitucionais quanto à sua eficácia, dotada de coerência interna e correção conceitual, de modo a compreender a capacidade eficacial da totalidade dos enunciados normativos da Constituição. Mas o acerto científico da teoria não a isenta de críticas, e o propósito central deste estudo é evidenciar que as teorias dogmáticas das normas constitucionais quanto à sua eficácia tendem a comprometer a efetividade dos direitos fundamentais sociais, na medida em que conduzem a uma interpretação meramente subsuntiva das normas constitucionais aos conceitos doutrinários e desestimulam ações orientadas à otimização e concretização dos direitos sociais.

\section{III - Concepção pragmática das normas constitucionais de direitos sociais}

\section{Crítica à natureza semântica e estática das teorias dogmáticas das normas constitucionais}

A ampla influência que as teorias dogmáticas das normas constitucionais exercem na hermenêutica constitucional brasileira, na doutrina como no direito judicial, não elude a repercussão negativa que sua aceitação acrítica e resignada produz para a efetividade da Lei Fundamental, situação que se mostra nítida no exame das normas definidoras de direitos sociais, programáticas ou não.

Essas classificações das normas constitucionais quanto à eficácia partem de uma concepção semântica dos enunciados normativos, restringindo-se a aferir a sua eficácia real ou potencial a partir da leitura do texto estático da norma, sem conceder espaço para uma apreciação da norma em ação. Trata-se, portanto, de uma concepção semântica e estática das normas constitucionais.

A concepção que desenvolvo a seguir pretende esboçar uma teoria pragmática das normas constitucionais, orientada para além do significado estático do enunciado normativo, a fim de apreender a dinâmica da eficácia da norma quando posta em ação. Essa proposta, entretanto, tem um campo de aplicação modesto em relação à totalidade dos estudos sobre as normas constitucionais, porquanto pretende abrigar tão-somente o exame das normas constitucionais definidoras de direitos sociais. Evidente, então, que o núcleo do estudo é composto pelas normas que, historicamente, receberam conceitos semânticos redutores da eficácia normativa, notadamente as assim chamadas normas programáticas.

A percepção do conflito entre concepções estáticas e dinâmicas das normas jurídicas foi bem apresentada por Luigi Ferrajoli, em estudo centralizado nos direitos fundamentais, com ênfase nos direitos sociais. Ferrajoli expõe a existência de dois distintos e contrapostos sistemas de direito positivo, um sistema nomoestático, caracterizado pelo domínio da lógica-formal no âmbito da eficácia da norma, e outro nomodinâmico, no qual a eficácia da norma condiciona-se por fatos empíricos inerentes ao próprio conteúdo da norma: 
"En un sistema nomoestático, com es la moral y como sería un sistema de derecho natural fundado únicamente sobre principios de razón, las relaciones entre figuras deónticas son relaciones puramente lógicas: dado un derecho, o sea, una expectativa jurídica positiva ou negativa, existe para otro sujeto la obligación o la prohibición correspondente; dado un permiso positivo, el comportamiento permitido no está prohibido y, portanto, no existe la obligación correlativa; dada una obligación, no está permitida la omisión del comportamiento obligatorio $\mathrm{y}$, por conseguiente, no existe el correlativo permiso negativo, mientras que sí existe el correspondiente permiso positivo. ${ }^{30}$

Nesse tipo de sistemas, a existência ou a inexistência das figuras deônticas depende e é deduzida da existência daquelas consideradas "dadas". Assim inexistem antinomias e lacunas, já que quando duas normas entram em contradição, uma deve ser excluída como inexistente, mais do que como inválida. "Éste es el sentido del principio iusnaturalista veritas autoritas facit legem: en ausencia de criterios formales de identificación del derecho existente, los únicos criterios disponibles son los criterios lógicos y racionales de tipo inmediatamente sustancial, es decir ligados a lo que dicen las normas." 31

Mas, adverte Ferrajoli, se este raciocínio é verdadeiro para os sistemas "nomoestáticos", não o é para os "nomodinâmicos", nos quais a existência ou inexistência de uma situação jurídica, vale dizer, de uma obrigação, uma proibição, uma permissão ou uma expectativa jurídica, depende da existência de uma norma positiva que a preveja, a qual, por sua vez, não é deduzida de outras normas, mas induzida, como fato empírico, do ato de sua produção. E acrescenta: "Por conseguiente, es muy posible que, dado un derecho subjetivo, no exista - aun cuando debiera existir - la obligación o la prohibición correspondiente a causa de la (indebida) inexistencia de la norma que la prevé. Como tambiém es posible que, dado un permiso, exista - aun quando no debiera existir - la prohibición del mismo comportamiento a causa de la (indebida) existencia de la norma que la prevé." 32

Embora o enfoque que as concepções estática e dinâmica das normas jurídicas recebam de Ferrajoli seja distinto daquele que será empregado neste ensaio, ele funciona como ponto de partida adequado para a compreensão da proposta. Em um sistema nomoestático de direito, a composição da norma possui à partida todos os elementos necessários para que ela gere seus efeitos essenciais, seja qual for a categoria deôntica - mandado, proibição ou permissão - à qual pertença. A norma jurídica é, neste caso, auto-suficiente no quesito eficácia, não carecendo de fatores exógenos à sua composição normativa para ser plenamente eficaz.

O modelo estático revela-se compatível com as normas constitucionais definidoras dos direitos fundamentais de corte liberal, pertencentes ao status negativus.

30 FERRAJOLI, Luigi, Derechos y garantías, Editorial Trotta, Madrid, 1999, p. 60.

31 FERRAJOLI, Luigi, ob. cit., p. 60.

32 FERRAJOLI, Luigi, ob. cit., p. 60. 
Os direitos fundamentais individuais têm sua eficácia plena assegurada desde sua própria conformação normativa interna, porquanto os elementos essenciais da respectiva relação jurídica, sujeitos ativo e passivo e objeto da prestação pertinente, estão predeterminados na norma, dispensando fatores externos para sua concretização.

Esse esquema, contudo, é nitidamente incapaz de apreender o caráter complexo da eficácia das normas constitucionais definidoras de direitos sociais. Nesse caso, a norma em regra não tem auto-suficiência deôntica para engendrar sua eficácia essencial, cuja efetivação carece de fatores exógenos ao enunciado normativo. Ou seja, a concretização da eficácia da norma não pode dar-se prescindindo de sua comunicação com elementos metanormativos, e daí sua conformação necessariamente dinâmica, em contraposição com o modelo nomoestático, característico de normas constitucionais definidoras de direitos fundamentais individuais.

Ferrajoli atribui a estrutura nomodinâmica a todo o direito moderno, embora não esclareça sobre a persistência de espaços nomoestáticos nos sistemas jurídicos contemporâneos. Na sua classificação, a estrutura nomodinâmica do direito moderno impõe distinguir os direitos e suas garantias, e para tanto os direitos liberais como os direitos sociais somente podem obter garantia no sentido que empresta ao conceito de nomodinâmica.

No entanto, no sentido dessas observações, parece-me cientificamente correto, ciente é claro da mudança de enfoque, dizer que a eficácia jurídica das normas jusfundamentais de corte liberal pode ser extraída suficientemente do próprio enunciado normativo ${ }^{33}$. É esta auto-suficiência deôntica que possibilita a sua adequação ao modelo estático, porque a garantia jurídica desses direitos pode ser extraída diretamente do conteúdo da norma. Para garantir a liberdade de imprensa, a proibição de discriminação racial ou o direito de propriedade, os conteúdos normativos expressos no texto constitucional revelam-se suficientes para assegurar a eficácia da norma, porque não dependem, para tornarem-se eficazes, de fatores exógenos ao próprio preceito ou que não estejam dados no próprio sistema normativo.

No que concerne às normas constitucionais definidoras de direitos sociais, programáticas ou não, freqüentemente será insuficiente a estrutura normativa para a geração da eficácia essencial prevista na norma. Isso porque elas possuem um déficit normativo imanente que só pode ser suprido através da comunicação do seu programa normativo com fatores externos, geralmente metajurídicos. Por isso é que são classificadas como nomodinâmicas, porque a sua concretização é sempre dependente de idéia de law in public action.

Em verdade, Ferrajoli percebe a pertinência dessa distinção, como se observa na seguinte passagem de seu ensaio:

33 A mudança de enfoque deve-se a que a concepção exposta no ensaio associa as categorias da estática e da dinâmica à capacidade da norma ser eficaz a partir dos seus próprios elementos normativos, ao passo que a perspectiva de Ferrajoli está ligada à formação do comando normativo a partir do enunciado da norma. 
"Cuestión distinta es que las garantías sean realizables en concreto. Ciertamente, la enunciación constitucional de los derechos sociales a prestaciones públicas positivas no se ha visto acompañada de la elaboración de garantías sociales o positivas adecuadas, es decir, de técnicas de defensa y de justificabilidad parangolables a las aportadas por las garantías liberales o negativas para la tutela de los derechos de liberdad" 34 .

Pois bem, essa insuficiência normativa das normas constitucionais de direitos sociais, que faz com que a geração dos seus efeitos essenciais e, portanto, a garantia efetiva desses direitos dependa de uma dinâmica marcada pela comunicação da norma com fatores exógenos, determina uma abordagem dogmática completamente distinta daquela imposta pelas teorias dominantes sobre eficácia das normas constitucionais. Esse fechamento à realidade das categorias desenvolvidas pelas classificações semânticas deriva, aliás, da sua gênese conceitualista, como já referi. A derivação de conceitos a partir, exclusivamente, do exame dos elementos normativos estáticos produz conceitos formais, desligados da vida e de existência meramente intelectual ${ }^{35}$.

As classificações semânticas que possuem hoje a hegemonia científica no Direito Constitucional brasileiro não prejudicam a garantia dos direitos liberais, mas quando pensamos sobre seu reflexo em relação aos direitos sociais, é fácil perceber que o efeito dessas classificações é, para dizer o mínimo, altamente inibidor da luta pela garantia desses direitos. Ao estabelecer, no plano teórico, com a legitimidade científica de uma aceitação ampla pela doutrina e pela jurisprudência, que determinadas normas constitucionais não são capazes de gerar efeitos, e portanto de garantir direitos, sem a interposição de ações afetadas ao legislador e ao administrador, essas teorias aliviam os intérpretes da constituição, e muito especialmente a jurisdição constitucional, da responsabilidade de produzir uma hermenêutica constitucional comprometida com a eficácia da Lei Fundamental.

A recepção acrítica pela jurisprudência dessas classificações contribuiu, e continua a contribuir, para o desencanto generalizado da sociedade brasileira com o constitucionalismo social. A despeito da existência de focos progressistas no direito judicial, que são crescentes nos últimos anos, é ainda dominante na doutrina o recurso às categorias de normas de eficácia limitada, programáticas ou de legislação, para eludir a garantia jurisdicional dos direitos sociais previstos na Constituição Federal. A resistência a uma concepção pragmática das normas constitucionais é difundida e consistente, e para legitimar-se como cientificamente correta vale-se exatamente da hegemonia absoluta daquelas teorias no âmbito doutrinário.

O caráter semântico dessas classificações gera, como subproduto, uma criptoneutralidade ideológica acerca dos pressupostos metajurídicos que subjazem à temática da garantia dos direitos sociais. O argumento de maior peso em favor da injusticiabilidade dos direitos sociais, no plano de uma teoria normativa, sempre foi

34 FERRAJOLI, Luigi, ob. cit., p. 63.

35 WIEACKER. Franz, História do Direito Privado Moderno, p. 458. 
centrado no princípio da separação dos poderes. A eficácia das normas jusfundamentais sociais seria indecidível na esfera judicial porque depende de aspectos que refogem ao domínio normativo, e cujo poder de decisão concerne às esferas legislativa e administrativa. Fecha-se o círculo teórico das classificações semânticas com essa justificação política que, em relação à dogmática jurídica, é nitidamente centrífuga, porquanto demite o intérprete jurídico, o juiz principalmente, do seu compromisso central, que é o de conectar a ordem normativa ao mundo fático.

O estudo propõe, como resposta às insuficiências e incorreções das teorias analisadas, uma concepção pragmática das normas constitucionais, caracterizada pelo aprofundamento do compromisso da ação judicial com a eficácia prática dos direitos sociais. É uma teoria pragmática, porque está dirigida à satisfação instrumental de uma finalidade predeteminada, a eficácia dos direitos sociais. E procura demonstrar a possibilidade de responder afirmativamente às questões centrais que envolvem os direitos sociais: $1^{\circ}$ ) se os indivíduos, considerados singularmente ou como coletividade, possuem direitos subjetivos a prestações estatais e políticas públicas de conteúdo social; $2^{\circ}$ ) se o Poder Judiciário tem legitimidade e competência para assegurar a fruição de direitos sociais e provocar a execução das prestações e políticas sociais do Estado $^{36}$.

A base teórica do estudo está francamente sustentada na pragmatic turn do pensamento filosófico operada principalmente desde o desenvolvimento da teoria do agir comunicativo pelo filósofo alemão Jürgen Habermas, a partir dos anos oitenta, que vem exercendo crescente influência na filosofia prática européia e americana, com repercussão decisiva na teoria do direito desde que Habermas a transpôs na teoria discursiva do direito formulada em Faktizität und Geltulg (Faticidade e Validade), obra de $1992 .{ }^{37}$

\section{A teoria discursiva do Direito e a eficácia dos direitos sociais}

A filosofia do direito desenvolvida por Habermas a partir da teoria do agir comunicativo deriva da superação, ou, melhor dizendo, da sofisticação da razão prática em razão comunicativa, que apreende o caráter inescapavelmente comunicativo das relações sociais e o converte em um mecanismo de produção de decisões públicas legítimas, a partir de pressupostos discursivos formais que devem conduzir à prevalência do melhor argumento, em um ambiente onde o discurso público seja aberto a todos e livre de coações externas e internas. No plano do direito, sustenta, apenas uma teoria discursiva pode dar conta da conexão entre faticidade e validade.

Um dos aspectos nucleares da razão comunicativa de Habermas reside na compreensão de que o agir comunicativo é orientado para o entendimento mútuo

36 Cf. LOPES, José Reinaldo de Lima, Direito subjetivo e direitos sociais; o dilema do Judiciário no Estado Social de Direito, publicado em Direitos Humanos, direitos sociais e Justiça, organizador José Eduardo Faria, Editora Malheiros, 1998, p. 130.

37 HABERMAS, Jürgen, Direito e Democracia, entre Faticidade e Validade, Editora Tempo Universitário, Rio de Janeiro de 1997. 
dos participantes do discurso, mediante performances comunicacionais que utilizam a linguagem como medium que veicula argumentos dotados de pretensões de validade $^{38}$. O agir comunicativo é dirigido por uma ética discursiva cujo objetivo é explicar que é possível, ante um conflito normativo, obter um acordo racionalmente motivado, através de um modelo de diálogo aberto e irrestrito, ao qual todos os possíveis afetados pela decisão têm igual acesso e onde, ao final, prevalece a força o melhor argumento ${ }^{39}$.

Esse novo paradigma da teoria do direito pode, a nosso ver, alterar decisivamente a teoria das normas constitucionais, particularmente a abordagem sobre a eficácia das normas jusfundamentais de direitos sociais. Como já foi dito, as concepções semânticas das normas constitucionais tendem a inibir a atividade de concretização desses direitos na medida em que o conceito que aplicam às normas que os definem concebe-as como de eficácia jurídica precária ou inexistente, carente de intervenção legislativa ou administrativa para atingir os fins da norma.

Tal concepção preserva a norma no ponto estático do enunciado normativo, sem impulsioná-la a interagir com os fatores que lhe são inerentes, mas que lhe são também externos. Vale dizer, sem submetê-la a uma dinâmica normativa. Parece-me que essa debilidade normativa pode ser superada a partir de uma concepção pragmática das normas constitucionais definidoras de direitos sociais, que a sujeite a um processo discursivo onde os participantes do debate apresentem racionalmente seus argumentos, de modo aberto e livre de coações, externas e internas, e visando ao mútuo entendimento, para que ao final prevaleça o melhor argumento.

A vantagem dessa teoria é que nenhum direito social é ineficaz na partida, no plano abstrato e estático do enunciado normativo. Todo e qualquer direito social previsto na Constituição Federal é normativamente capaz de gerar direitos subjetivos, e a garantia efetiva dos direitos deverá ser aferida, sem limites preestabelecidos dogmaticamente, dentro dos processos de discursos públicos e, para o que interessa mais de perto ao nosso tema, dentro de processos judiciais da jurisdição constitucional.

Sem contar com uma teorização prévia e exortativa, a jurisprudência vem discretamente experimentando a justiciabilidade dos direitos fundamentais sociais, fenômeno observado por Ferrajoli, o qual afirma que a experiência jurídica contemporânea tem sinalizado para a viabilidade de assegurar-se a eficácia prática dos direitos sociais através do apelo à jurisdição:

"la tesis de la no susceptibilidade de tutela judicial de estos derechos resulta desmentida por la experiencia jurídica más reciente, que por distintas vias

38 Sobre a Filosofia do Direito de Habermas foram referenciais as obras de MOREIRA, Luiz, Fundamentação do Direito em Habermas, Co-Edição Mandamentos Livraria e FortLivros, Belo Horizonte, 1999; CITTADINO, Gisele, Pluralismo, Direito e Justiça Distributiva, Lumen Juris, Rio de Janeiro, 1999; e GIMBERNAT, José Antônio (Editor) La Filosofía Moral y Política de Jürgen Habermas, Biblioteca Nueva, Madri, 1997.

39 Cf. CITTADINO, Gisele, Pluralismo, Direito e Justiça Distributiva, pp. 107/118. 
(medidas urgentes, acciones reparatorias y similares) ha visto ampliar-se sus formas de protección jurisdiccional, en particular en lo que se refiere al derecho a la salud, a la seguridad social y a una retribuición justa." 40

Essa mudança de perspectiva do papel da justiça na luta pela garantia dos direitos sociais supera o entrave que as teorias semânticas impõem a priori à consecução desse objetivo. Até hoje, a proposição de uma ação judicial visando garantir um direito social tende a ser rejeitada conceitualmente, ou seja, pelo mero fato de tratar-se de demanda de direito a prestação estatal, sob o argumento de que a norma que dá origem ao suposto direito é de eficácia limitada, ou porque é programática, ou porque depende de legislação completiva.

Uma concepção pragmática das normas constitucionais, que as compreenda como estruturalmente nomodinâmicas, anuncia que não se pode extrair a eficácia da norma diretamente do seu enunciado. A eficácia prática da norma, que permita a garantia efetiva do direito social previsto no texto constitucional, surgirá ou não conforme o resultado do processo judicial marcado por uma ética discursiva, que impõe aos participantes do processo um agir comunicativo, portanto voltado para o entendimento mútuo, veiculado através de argumentos apresentados, debatidos $\mathrm{e}$ investigados livremente, até que uma solução consensual seja atingida, ou que o juiz decida, à luz de tais condições discursivas e mediante uma fundamentação racional e atenta ao debate.

Para melhor situar a teoria esboçada, valho-me de casos judiciais típicos cujas soluções demonstram a viabilidade jurídica da garantia de direitos sociais através de processos judiciais, desde que submetidos à ética discursiva.

Tem sido frequiente $o$ ajuizamento de ações com o objetivo de obter a condenação do Estado ao fornecimento de medicação ou tratamento médico, de que dependa a saúde ou a vida do autor da ação, quando não é fornecido pelo sistema público de saúde e a pessoa necessitada não tem condições financeiras de adquirir no mercado. A história recente da jurisprudência desses casos, que, diga-se, não são poucos, evidencia haver uma tendência ao acolhimento da pretensão, mediante um procedimento hermenêutico progressista que concretiza as normas constitucionais que prevêem o direito social à saúde (art. $6^{\circ}$ e art. 196, caput, da Constituição Federal). Não há, efetivamente, maior complexidade na condenação do Estado a custear, para algumas dezenas ou centenas de pessoas vitoriosas em ações individuais, medicações ou tratamentos médicos que são comprovadamente indispensáveis para a saúde ou a vida deles ${ }^{41}$.

A questão pode ser, contudo, mais intrincada. Imagine-se uma ação coletiva, proposta pelo Ministério Público ou por uma associação civil, visando à condenação

40 FERRAJOLI, Luigi, ob. cit., p. 64.

41 É copiosa a jurisprudência desse tipo de casos. A título de exemplo, reporto-me ao Recurso Especial n. 127.604-RS, julgado pelo Superior Tribunal de Justiça, Rel. Min. Garcia Vieira, publicado no DJ n. 50, de 16.03.98, e aos julgados do Tribunal de Justiça do Estado do Rio Grande do Sul publicados na Revista de Jurisprudência do Tribunal, volumes 189/409, 184/277, 187/184, $188 / 270$ e $182 / 386$. 
da União, do Estado ou do Município a custear gratuitamente, digamos transplantes de medula óssea, a todos os portadores de leucemia. A questão ganha em complexidade porque, nesse caso, a condenação implicaria em um custo financeiro significativo para o orçamento do ente federativo; certamente exigiria a criação de um programa governamental.

Situação similar e dotada da mesma problemática esteve presente em ação civil pública movida pelo Ministério Público do Estado do Rio Grande do Sul para obter condenação do Município de Porto Alegre a comprar leitos hospitalares pediátricos, inclusive em UTIs, em entidades privadas, sempre que crianças ou adolescentes necessitarem de internação imediata e não houver leitos do Sistema Único de Saúde disponíveis. A ação foi julgada procedente, constando do voto condutor a ratio decidendi da decisão:

"É consabido que a Saúde Pública é obrigação do Estado em abstrato, desimportando qual a esfera de poder que, efetivamente, a cumpre, pois a sociedade que contribui e tudo paga, indistintamente, ao ente público que lhe exige tributos cada vez mais crescentes, em todas e quaisquer esferas de poder estatal, sem que a cada qual seja especificada a destinação desses recursos." 42

Adiante, o Desembargador Wellington Pacheco Barros utiliza argumento de extrema importância para este estudo:

"Por outro lado, tampouco sensibiliza o argumento atinente com a necessidade de previsão de dotação orçamentária para tais despesas, porquanto tal não incurribe à administração da justiça, mas apenas ao administrador que deve atender as necessidades dos contribuintes, a saúde pública, entre tantas outras obrigações, especialmente aos mais necessitados e aos doentes."

Outra ação de tutela de direitos sociais paradigmática sobre o tema, igualmente proposta pelo Ministério Público, resultou na condenação do Estado do Rio Grande do Sul a instalar e manter programas de internação e semiliberdade para adolescentes infratores ${ }^{43}$. $\mathrm{O}$ acórdão expressamente assume que a decisão pretende conferir eficácia ao artigo 227 da Constituição Federal, que elenca diversos direitos fundamentais atribuídos às crianças e aos adolescentes e impõe ao Estado e à sociedade uma cláusula de prioridade absoluta na tutela dos direitos enumerados no dispositivo. $\mathrm{O}$ precedente ganha em importância pelo elevado nível das reflexões que os juízes, promotores, procuradores do Estado e finalmente desembargadores dispensaram a questões essenciais do problema da justiciabilidade dos direitos sociais.

42 Precedente do Tribunal de Justiça do Rio Grande do Sul, Apelação Cível n. 70000438135 , Quarta Câmara Cível, Relator Desembargador Wellington Pacheco Barros.

43 Acórdão publicado ern Revista de Jurisprudência do Tribunal de Justiça do Rio Grande do Sul, n. 182, p. 260. O recurso foi julgado pela $7^{\mathrm{a}}$ Câmara Cível em 12 de março de 1997 , e teve como relator o Desembargador Sérgio Gischkow Pereira, que proferiu o voto condutor. 
O tema que mereceu particular atenção dos participantes do processo foi a alegada ilegitimidade do Poder Judiciário para invadir espaço público de domínio exclusivo do Poder Executivo, que nesta esfera age segundo critérios discricionários próprios insubstituíveis por critérios judiciais. Após análises ponderadas e profundas dos argumentos formulados no processo e pela doutrina sobre o tema, os desembargadores, valendo-se amplamente da fundamentação da sentença de primeira instância, julgaram a ação procedente e condenaram o Estado do Rio Grande do Sul a "obrigação de fazer consistente em incluir no próximo orçamento verba suficiente para criar, instalar e manter em funcionamento programas de internação e semi-liberdade para adolescentes infratores", decisão restrita ao Município de Santo Ângelo, onde fora proposta a ação ${ }^{44}$.

No voto condutor, o relator para o caso, Desembargador Sérgio Gischkow Pereira, posiciona-se sobre o argumento da ilegitimidade judicial para aplicar diretamente normas constitucionais programáticas, cuja eficácia dependeria da prévia atuação administrativa:

"A apelação insiste em que a sentença invadiu esfera privativa do Poder Executivo, ingressando em aspectos de oportunidade e conveniência. Com a máxima vênia, não é disto que se trata quando se dá cumprimento a uma norma constitucional explícita. Não se argumente que a norma jurídica do art. $227 \mathrm{da} \mathrm{CF}$, em seu caput, é meramente programática, sob pena de mais uma vez deixar de se aplicar a Constituição com esta espécie de pretexto, o qual, infelizmente, vem servindo para não aplicá-la, muitas vezes no que tem de melhor." 45

Uma abordagem guiada por uma teoria semântica das normas constitucionais tenderia a afirmar que se trata de demandas fundadas em normas constitucionais de eficácia limitada, que carecem de um programa governamental ou de legislação para serem juridicamente eficazes, e portanto não podem ser objeto de garantia pela via judicial. A solução é, portanto, de lógica formal, meramente subsuntiva do caso apresentado aos conceitos desenvolvidos pela teoria. Cuida-se, pois, de decisão típica do domínio da jurisprudência dos conceitos.

Já a abordagem judicial conduzida pela teoria pragmática ou discursiva das normas constitucionais de direitos sociais exigirá um processo deliberativo aberto prévio, que condicione as condutas das partes a uma ética discursiva voltada o entendimento mútuo, a fim de que se obtenha uma solução consensual ou uma decisão judicial que reflita o melhor argumento. Os autores que propuseram as ações poderão apresentar provas da necessidade e da qualidade do tratamento ou do programa, da

44 A referência às decisões judiciais citadas no texto não significa que sejam elas casos exemplares da concepção proposta neste estudo, mas tão-somente que são representativas da tendência atual de superação da teoria da injusticiabilidade dos direitos sociais. Sou grato a José Guilherme Giacomuzzi por apontar a necessidade de explicar esse aspecto.

45 Acórdão citado, p. 282. 
viabilidade técnica, financeira e orçamentária do seu custeio através de recursos públicos, e o ente federativo poderá oferecer, se assim entender, argumentos e materiais em sentido contrário, no sentido da possibilidade de soluções alternativas mais acessíveis, ou da impossibilidade de custeio através de recursos públicos, em face das limitações orçamentárias, ou da existência doutras prioridades na aplicação de recursos públicos.

Essa compreensão do processo judicial cujo objeto envolva garantia de direitos sociais determina, é claro, uma ampla e profunda modificação dos modelos de conduta das partes do processo, desde o juiz, passando pelas partes e seus defensores, do Ministério Público, quando atue como fiscal da lei, e de todo terceiro que, de qualquer modo, tome parte da discussão. Exige-se uma participação mais ativa e dialógica, mediante uma performance processual sofisticada e ética, destinada ao entendimento mútuo, ainda que para tanto se imponham, e sofram essa imposição do juiz, limites a ações estratégicas que visem apenas ao êxito na ação.

A redefinição do modelo processual proposto para as ações cujo objeto seja a concretização de direitos sociais implica uma revisão do formato histórico dos processos judiciais herdado do direito justinianeu e da canonística, caracterizado pelo afastamento do juiz dos fatos diretos, pela redução do debate judicial aos documentos vertidos para os autos (trata-se, portanto, de processos de autos), pela esquematização rígida das performances processuais e pelo monopólio da escrita na articulação dos argumentos. Como descreve Wieacker, esse modelo processual, até hoje predominante nos países de Direito romano-germânico, conduziu ao processo articulado, que decompõe as alegações das partes e as manifestações do juízo em posições isoladas de ataque, defesa e contra-ataque (actio, exceptio e replica) progressivamente encadeados, mediante a administração meramente fiscalizadora do juiz, de quem apenas espera-se a eleição radical de uma das posições defendidas na causa ${ }^{46}$.

É nítido, entretanto, que “a conformação do articulado em 'posições independentes', com a sua desmedida extensão e arrastar do processo, sobretudo em virtude dos meios jurídicos próprios para cada uma, acaba precisamente por paralisar a dialética natural deste processo de controvérsia e põe assim em perigo (tanto como o caráter indireto e a forma escrita) a integração social espontânea do direito no processo" 47 .

A adoção de um modelo comunicacional aberto e dialógico permite, ao contrário, o acréscimo de legitimidade de uma decisão pela eficácia ou ineficácia de um direito fundamental social tomada em processo judicial que atenda a esses pressupostos. $\mathrm{O}$ caráter democrático é acentuado, na medida em que a solução reflete o melhor argumento, resultante de um debate potencialmente aberto a todos os afetados pela decisão, a qual, na medida em que é fruto da participação de todos, deve ser compreendida como uma decisão tomada pelos próprios participantes, ainda que contra sua vontade original. 
A capacidade de legitimação democrática que resulta dos discursos públicos abertos vem sendo ressaltada pelas teorias procedimentais do direito, que exercem larga influência no pensamento constitucional contemporâneo. A concepção de democracia responsiva (responsive democracy) de Robert Post, por exemplo, fundada na idéia de free public discourse, busca reconciliar a autonomia individual com a auto-determinação coletiva através da subordinação das decisões governamentais a processos comunicativos "capazes de instilar nos cidadãos um senso de participação, legitimidade e identificação ${ }^{48}$. Frank Michelman, embora discorde da teoria procedimental pura desenvolvida por Robert Post, destaca na sua obra aspectos relevantes concernentes à legitimidade democrática resultante de processos abertos de discussão pública:

"quando um sistema de criação do direito, e os valores públicos que o preenchem com direção e força, estão visível e constantemente sendo forjados e testados em um discurso público radicalmente livre, então esse sistema de criação do direito é algo com que cada habitante do país pode identificar-se como 'proprietário', responsável como tal por todas as leis que o sistema cria de tempo em tempo. O sistema e suas leis resultantes podem então ser considerados como livremente escolhidos por cada um, ao menos no sentido de que cada um pode ver o sisterna como urna representação autêntica da soma das preferências e opiniões com as quais os indivíduos têm, severa e livremente, contribuído para o ponto de fusão (meltingpot) do discurso público. Assim, um objetivo prático central da democracia responsiva é especificar as condições sociais, incluindo as condições legais, em que todos os indivíduos podem ter um senso justificado de contribuição efetiva e autônorna, através do discurso público, para o processo de criação da ordem social ern que eles vivem." ${ }^{49}$

Como disse Habermas, sobre o potencial legitimador desse modo de produção do direito, "Sob condições do discurso, que obrigam cada um a assumir a perspectiva dos demais membros e até de todos os outros, é possivel uma modificação racionalmente motivada das tomadas de posição originais. Como participantes de um tal processo de formação discursiva da opinião e da vontade, os cidadãos se conscientizam de seu direito de autodeterminação" ${ }^{50} \mathrm{e}$, adiante, "uma interpretação apoiada

48 POST, Robert, Constitutional Domains, Harvard University Press, Cambridge, 1995. As teorias procedimentais da democracia consolidaram-se no pensamento constitucional norte-americano a partir da obra clássica de John Hart Ely, Democracy and Distrust, de 1980, a despeito da vigorosa resistência que lhes opôs Ronald Dworkin, que desenvolve uma concepção substantiva da democracia, a qual sinteticamente se pode definir como uma teoria da democracia centrada na proteção dos direitos constitucionais; ver Uma Questão de Princípio, Martins Fontes, pp. 80/103, e Freedo$m$ 's Law, Harvard University Press, Cambridge, 1996, pp. 1/38.

49 MICHELMAN, Frank, Brennan and Democracy, Princeton University Press, New Jersey, 1999, p. 37.

50 HABERMAS, Jürgen, ob.cit., p. 339. 
numa teoria do discurso insiste em afirmar que formação democrática da vontade não tira sua força legitimadora da convergência preliminar de conviç̧ões éticas, $e$ sim de pressupostos comunicativos e procedimentos, os quais permitem que, durante o processo deliberativo, venham à tona os melhores argumentos" 51 .

São três, portanto, os fatores de legitimação da decisão que tutele efetivamente o direito social através do procedimento proposto: $1^{\circ}$ ) a participação comunicativamente aberta e igualitária dos afetados pela futura decisão; $2^{\circ}$ ) a existência de condições e procedimentos que permitam que a solução reflita o melhor argumento; $\left.3^{\circ}\right)$ que o melhor argumento possa ser aceito sem coação por todos os afetados pela decisão como resultante da sua capacidade de autodeterminação.

A teoria procedimental do direito desenvolvida pelo constitucionalismo norteamericano, como de resto a teoria discursiva e igualmente procedimental do direito de Habermas, preocupa-se essencialmente com a criação legítima do direito, como fica claro na leitura da passagem transcrita. No entanto, essa concepção procedimental e discursiva da criação jurídica, se possui um espectro de aplicação muito mais amplo e complexo, no campo propriamente do Direito como no campo politológico (sobretudo no caso das abordagens teóricas americanas), pode ter uma aplicação mais restrita, mas inteiramente pertinente no âmbito da jurisdição constitucional de tutela dos direitos sociais, na medida em que os processos judiciais permitam que $o$ indivíduo titular do direito fundamental, pessoalmente ou representado por instituição que o substitua na ação, discuta diretamente com o sujeito passivo da relação jusfundamental os fatores metajurídicos de que depende a efetividade do direito social.

Embora em outro contexto, Gilmar Ferreira Mendes propôs a abertura do processo judicial a procedimentos comunicativos. Em ensaio sobre a nova hermenêutica constitucional e a revisão de fatos e prognoses legislativos no âmbito da jurisdição constitucional, ele propugna pelo "desenvolvimento de técnicas que possibilitem decisões racionalmente fundadas por parte do órgão judicial de controle", sempre que a decisão sobre a constitucionalidade de atos normativos depender do exame de fatos e de prognoses legislativos.

Esse "modelo procedimental" poderia compor-se de provas técnicas, apresentação de pareceres de especialistas, de documentos e informações necessários, e inclusive a adoção do sistema de amicus curiae, através do qual a Suprema Corte norte-americana admite que terceiros estranhos ao processo de controle judicial da constitucionalidade de normas, afetados pela decisão ou apenas interessados nela, apresentem briefs (memoriais) expondo argumentos acerca do tema em discussão. Além desse excelente mecanismo de informação à corte, sugere Gilmar Ferreira Mendes que "a participação de diferentes grupos em processos judiciais de grande significado para toda a sociedade cumpre uma função de integração extremamente importante" ${ }^{52}$.

51 HABERMAS, Jürgen, ob. cit., p. 345.

52 MENDES, Gilmar Ferreira, Controle de Constitucionalidade: Hermenêutica Constitucional e revisão de fatos e prognoses legislativos pelo órgão judicial, publicado na Revista dos Tribunais, v. $766,08 / 99$, p. $11-28$. 
A fonte doutrinária da proposta de Gilmar Ferreira Mendes encontra-se no famoso ensaio de Peter Häberle intitulado "A sociedade aberta dos intérpretes da constituição", no qual o jurista germânico expõe o que denomina de "uma contribuição para a interpretação pluralista e procedimental da Constituição". Veja-se o que sustenta Häberle:

"Para a conformação e a aplicação do direito processual (constitucional) resultam consequiências especiais. Os instrumentos de informação dos juízes constitucionais - não apesar, mas em razão da própria vinculação à lei devem ser ampliados e aperfeiçoados, especialmente no que se refere às formas gradativas de participação e à própria possibilidade de participação no processo constitucional (especialmente nas audiências e nas intervenções). Devem ser desenvolvidas novas formas de participação das potências públicas pluralistas enquanto intérpretes em sentido amplo da Constituição. $O$ direito processual constitucional torna-se parte do direito de participação democrática." 53

A referência à instituição norte-americana do amicus curiae, amplamente utilizada pela Suprema Corte, revela-se de extrema pertinência para a abertura pluralista dos participantes do processo de jurisdição constitucional, porque permite que indivíduos e instituições públicas e sociais que não são parte formal do processo judicial, mas têm interesse no objeto da ação, prestem à corte, espontaneamente ou por requerimento do próprio órgão judicial, informações, dados, opiniões ou pareceres concernentes ao tema debatido na causa.

O resultado é uma ampliação quantitativa e qualitativa do debate jurídico, democratizando e pluralizando a participação social no conflito, sem que, contudo, os "amigos da corte" convertam-se em partes formais do processo, nele não podendo exigir produção de provas ou recorrer da sentença. Conforme Miguel Angel Ekmekdjian, sua função essencial é da de aportar pareceres e informações "en determinados casos contenciosos cuya sentencia puedan llegar a tener transcendencia institucional, es decir que no se limiten a los intereses particulares de las partes." ${ }^{4}$

A proposta de importação do instituto norte-americano para o direito processual brasileiro, formulada por Gilmar Ferreira Mendes, foi afinal parcialmente acolhida em dois textos legais recentes: a Lei n. 9.868, de 10 de novembro de 1999, que disciplina a ação direta de inconstitucionalidade e a ação declaratória de constitucionalidade perante o Supremo Tribunal Federal, e a Lei n. 9.882, de 3 de dezembro de 1999, que dispõe sobre o processo e julgamento da argüição de descumprimento de preceito fundamental ${ }^{55}$.

53 HÄBERLE, Peter, Hermenêutica Constitucional, A sociedade aberta dos intérpretes da Constituição: contribuição para a interpretação pluralista e 'procedimental' da Constituição, Sérgio Fabris Editor, 1997, pp. 47/48.

54 EKMEKDJIAN, Miguel Angel, El amicus curae en el Derecho Constitucional Argentino, Cadernos de Direito Constitucional e Ciência Política, n. 16, p. 80.

55 Sobre o projeto de lei que resultou na Lei n. $9.869 / 99$, produzido por comissão de juristas da 
O artigo $9^{\circ}, \S 1^{\circ}$, da Lei n. 9.898/99, prevê que “Em caso de necessidade de esclarecimento de matéria ou circunstância de fato ou de notória insuficiência das informações existentes nos autos, poderá o relator requisitar informações adicionais, designar perito ou comissão de peritos para que emita parecer sobre a questão, ou fixar data para, em audiência pública, ouvir depoimentos de pessoas com experiência e autoridade na matéria." $\mathrm{O} \S 2^{\circ}$ do artigo $9^{\circ}$ diz que o relator do processo poderá solicitar aos Tribunais Superiores e aos Tribunais federais e estaduais informações acerca da aplicação da norma impugnada, no âmbito da sua jurisdição.

$\mathrm{O}$ artigo $6^{\circ}, \S 1^{\circ}$, da Lei n. 9.882/99 dispõe que "Se entender necessário, poderá o relator ouvir as partes nos processos que ensejaram a argüição, requisitar informações adicionais, designar perito ou comissão de peritos para que emita parecer sobre a questão, ou, ainda, fixar data para declarações, em audiência pública, de pessoas com experiência e autoridade na matéria."

Os preceitos transcritos representam uma evidente recepção da figura do amicus curiae, cuja influência vislumbra-se na aceitação da participação de terceiros no processo de discussão sobre o objeto da ação. Amplia-se o círculo de intérpretes formais da constituição, ao permitir inclusive a ausculta doutros tribunais sobre a aplicação das normas jurídicas contestadas, e o leque de participantes do debate, ao introduzir a inquirição de peritos e especialistas no tema sub judice, a ser realizada em audiência pública. Não há expressa referência à aceitação de memoriais por terceiros interessados, tal como acontece no modelo norte-americano, mas se o pode inferir permitido nas autorizações para coleta de "informações".

No âmbito das ações de competência do Supremo Tribunal Federal, basta imaginar o ganho de qualificação e profundidade temática que se acrescentaria a uma ação direta de inconstitucionalidade que, por exemplo, pretendesse a declaração de nulidade, por afronta ao artigo $7^{\circ}$, IV, da Constituição Federal, de lei federal que fixa salário mínimo. A inquirição de técnicos do Governo Federal, de entidades representativas dos trabalhadores, dos empresários, de economistas de órgãos universitários ou do DIEESE por certo agregaria ao processo informações que qualificariam o debate e permitiriam uma decisão com alto grau de racionalidade e razoabilidade, em uma cenário discursivamente aberto, democrático e competente, capaz de desarmar pretensões meramente estratégicas e argumentos ideologizados.

E embora este novo instituto esteja previsto para ser aplicado nas ações direta de insconstitucionalidade, declaratória de constitucionalidade e de argüição de descumprimento de preceito fundamental, nada impede que se o estenda a outras espécies de demandas, tal como a ação civil pública, o mandado de injunção e a ação popular, ou qualquer ação que envolva prestação de jurisdição constitucional, valendo-se o juiz da interpretação extensiva para, entendendo pertinente, ampliar o elenco de participantes no debate processual.

qual foi membro Gilmar Ferreira Mendes, ver relatório elaborado pelo referido autor e publicado em obra da sua autoria, Direitos Fundamentais e Controle de Constitucionalidade, Celso Bastos Editor, 1998, p. 412, no qual destaca expressamente a influência do instituto do amicus curiae na elaboração das normas comentadas no texto. 
Como já assinalei, a assimilação da perspectiva comunicativa dos processos judiciais cujo objeto de debate seja a tutela de direitos sociais exige uma atitude inteiramente diferente dos seus participantes. Utilizando a terminologia típica da teoria do agir comunicativo de Habermas, as partes devem renunciar à ação estratégica em favor da ação comunicativa, através da qual as performances das partes envolvidas orientam-se para o entendimento, através do reconhecimento das pretensões de validez e de correção presentes nos argumentos dos demais, ao passo que a ação estratégica é voltada exclusivamente para o êxito no debate. Como disse Habermas, "enquanto no agir estratégico um 'atua' sobre o outro para 'ensejar' a continuação desejada de uma interação, no agir comunicativo um é motivado racionalmente pelo outro para uma ação de adesão" 56 .

É preciso, portanto, fundar uma ética discursiva que assente pressupostos formais do processo discursivo capazes de conferir legitimidade para as soluções normativas encontradas no debate ancorado no agir comunicativo. $O$ princípio da ética discursiva referese a um procedimenlo caracterizado por condições formais que permitam o mais acurado exame das pretensões de validade normativas expostas pelos participantes do discurso ${ }^{57}$. No processo judicial, a adoção da ética discursiva tanto exige das partes uma renovação da atitude estratégia convencional, quando do juiz uma postura exortativa, impositiva e controladora das condições ideais para a comunicação voltada para o entendimento.

Esse procedimento de aplicação e concretização dos direitos fundamentais sociais a prestações estatais é coincidente com a própria contingência da inserção dos direitos fundamentais em uma ordem jurídica positiva específica, que determina amplamente o próprio conteúdo e o significado desses direitos em um determinado Estado e em um determinado momento histórico.

Como advertiu Vieira de Andrade, a aceitação científica de que a categoria dos direitos fundamentais é constituída, enquanto matéria juridicamente válida, pela sua positivação em uma certa ordem jurídica, implica em que " mesmo que as formulações (em diferentes constituições, em épocas e regiões distintas) sejam idênticas, $o$ sentido dos direitos fundamentais não é o mesmo quando estão integrados numa Constituição concreta. As normas que os contêm são interpretadas, reguladas $e$ aplicadas no quadro global da Constituição e sofrem, por isso, pelo seu lado e necessariamente, a influência das fórmulas de organização do poder político, dos princípios constitucionais gerais e mesmo das posições relativas entre os diversos direitos. A conotação e o contexto dos direitos determinam o ambiente em que juridicamente vivem, condicionando, por essa via, a sua própria subsistência" ${ }^{58}$.

Efetivamente, o juiz aplicador dos direitos fundamentais não pode concretizar uma idéia abstrata, absoluta ou semântica da Constituição. Ele precisa, assim como os participantes de um debate juridicamente qualificado sobre os direitos fundamen-

56 HABERMAS, Jürgen, Consciência Moral e Agir Comunicativo, Ed. Tempo Brasileiro, p. 79.

57 HABERMAS, Jürgen, Consciência Moral e Agir Comunicativo, p. 126.

58 VIEIRA DE ANDRADE, José Carlos, Os Direitos Fundamentais na Constituição Portuguesa de 1976, Ed. Almedina, Coimbra, 1987, p. 32. 
tais, operar sobre eles tais como se apresentam na realidade constitucional concretamente existente, e harmonizar a inescapável tensão entre a validade do direito e a faticidade do real.

E para aplicar uma constituição repleta de direitos sociais de matizes os mais diversos, que absorvem os setores essenciais da experiência social humana, em uma sociedade marcada por fatores econômicos, políticos, culturais e sociais de extrema complexidade e, não raramente, dramaticidade, o processo de decisão constitucional não pode ser um espetáculo de atitudes arrogantes, fechadas sobre si. Se a Constituição encerra um efetivo compromisso público com os princípios e direitos que assume, e não um mero artifício de preservação de uma sociedade injusta, somente um processo comunicativamente aberto e reflexivo, que mobilize a dinâmica da norma constitucional com os elementos metanormativos a ela inerentes, poderá responder com êxito às suas melhores intenções. O que este estudo procura demonstrar é que a arena judicial pode ser, alteradas certas concepções, o cenário adequado para esta luta.

\section{IV - Objeções}

\section{Cobertura insuficiente}

Um objeção que se poderia levantar contra uma teoria pragmática da eficácia das normas definidores dos direitos sociais é de que ela afinal retira destas normas a capacidade de gerar efeitos imediatos, sempre que for possível, em face da prévia interposição do procedimento discursivo descrito. A teoria, entretanto, está voltada sobretudo para aquela categoria que a teoria do direito anglo-americana denomina de "casos difíceis" (hard cases) ${ }^{59}$, nos quais a norma jusfundamental não permite que se extraia diretamente do enunciado normativo o direito social nela previsto, $e$ não para os "casos fáceis", em que a norma constitucional contém elementos normativos suficientes para ser aplicada diretamente (como ocorre, por exemplo, com grande parte dos direitos sociais do trabalhador, do art. $7^{\circ}$ da CF), ou mesmo naquelas hipóteses em que a norma constitucional, embora vaga, fluída e imprecisa, contém suficiente regulamentação legal infraconstitucional, que assegure a tutela do direito social disposto no texto constitucional (como ocorre, por exemplo, com a maioria dos direitos sociais previdenciários).

E não é restrita a pretensão da teoria, na medida em que grande parte das normas jusfundamentais sociais possui caráter vago, aberto, fluído, impreciso, que torna a sua garantia prática um "caso difícil", sejam direitos sociais expressamente previstos

59 A exposição da filosofia do direito de Ronald Dworkin, sobretudo em suas duas grandes obras, Taking Rights Seriously e Law's Empire, é estruturada sobre essa distinção, casos difíceis e casos fáceis, como técnica para elaborar sua crítica ao positivismo de Hart. A metodologia utilizada naquelas obras teve, como parece claro, grande influência sobre a construção deste estudo, de sorte que este tópico exige a pré-compreensão dessa fundamental distinção da teoria de Dworkin. 
na Constituição, sejam direitos sociais derivados de normas jusfundamentais "adscritas", na concepção formulada por Robert Alexy ${ }^{60}$. E o espectro de abrangência da teoria abarcaria os direitos sociais cujas normas-fonte tenham uma composição normativa insuficiente, e cuja garantia prática dependa de elementos normativos e valorativos que não se encontram na norma, e de elementos empíricos somente encontráveis quando a norma é submetida à ação comunicativa.

Assim ocorre, por exemplo, com os direitos sociais enumerados no artigo $6^{\circ} \mathrm{da}$ Constituição Federal, onde se encontra o "coração" do subsistema de direitos fundamentais a prestações estatais. Afirma a norma que são direito sociais a educação, a saúde, o trabalho, a moradia, o lazer, a segurança, a previdência social, a proteção à maternidade e à infância, a assistência aos desamparados. Alguns desses direitos sociais encontram suficiente normatividade no âmbito da própria Constituição, como os direitos de proteção do trabalhador e à previdência social. Outros estão suficientemente regulados no plano infraconstitucional, como sucede com a proteção da infância, desde a edição do Estatuto da Criança e do Adolescente.

Mas remanescem carentes de suficiente normatividade direta vários outros direitos sociais, cujo exercício torna-se problemático exatamente como decorrência desse déficit. Além disso, a própria disciplina normativa dos direitos sociais, disposta no texto constitucional ou regulada por lei ordinária, pode não exaurir toda a potencialidade jurídica dos direito fundamentais sociais, e portanto o seu gozo efetivo dependerá de um mecanismo de concretização. E a tutela judicial, através de um modelo processual marcado pela ética discursiva antes exposta, parece consistir no mais eficiente instrumento de garantia desses direitos.

\section{Ilegitimidade democrática}

A mais forte objeção que se pode aduzir a uma teoria pragmática das normas jusfundamentais sociais é o seu caráter "não-democrático", na medida em que transfere ao Poder Judiciário o debate e a decisão sobre a eficácia de normas que impõem ao Estado o provimento de prestações de matriz econômica aos indivíduos e à sociedade. Essa objeção, entretanto, deriva da incompreensão da natureza intrinsecamente contra-majoritária dos direitos fundamentais. Conforme assinala Robert Alexy, "El sentido de los derechos fundamentales consiste justamente en no dejar en manos de la majoría parlamentaria la decisión sobre determinadas posiciones

60 ALEXY, Robert, Teoria de los Derechos Fundamentales, p. 66. Normas jusfundamentais adscritas, segundo a definição deste autor, são normas de direito fundamental que nāo estão expressamente previstas no texto constitucional, mas que podem ser aditadas a normas de direitos fundamentais expressas, a partir de uma "fundamentação jusfundamental correta". A propósito dessa temática, Alexy faz afirmação que, conquanto genérica, vem ao encontro do que se vem expondo neste estudo: "Con todo, las normas adscritas ponen de manifiesto que la argumentación iusfundamental juega un papel decisivo en la respuesta a la cuestión acerca de qué es lo que vale desde el punto de vista de los derechos fundamentales", ob. cit., p. 80. 
del individuo, es decir, en deliminar el campo de decisión de aquella y es propio de posiciones iusfundamentales el que pueda haber desacuerdo sobre su contenido" ${ }^{\circ}$.

Essa crítica desconsidera a supremacia constitucional em beneficio de uma concepção majoritária de democracia, fundamentada na idéia de soberania popular, cuja consequêencia é debilitar o programa constitucional ao torná-lo refém das vontades exercitadas pelos poderes Legislativo e Executivo, supostamente portadores de uma legitimidade democrática extraída da representatividade eleitoral, por essa razão recusada ao Poder Judiciário.

A objeção é sustentada por uma concepção conservadora de divisão estanque de poderes, que restringe a atuação do Poder Judiciário na tarefa de concretização da constituição, porque parte de uma perspectiva ex parte principis, e não ex parte populi, como exige um estado democrático constitucional. De fato, a separação de poderes e os demais elementos constitutivos da organização estatal somente têm sentido enquanto peças - fundamentais, é verdade - do sistema de proteção dos direitos fundamentais assegurados na constituição; a divisão não tem um fim em si ou tampouco pode autorizar a invocação da comodidade do exercício das funções governamentais contra o objetivo da garantia dos direitos, realidade que já os redatores do The Federalist haviam intuído: "the real welfare of the great body af the people, is lhe supreme oNect to be pursued; and no form of government whatever has any other value titan as il may be fitted for the attainmenl of this object". ${ }^{2}$

Em verdade, a premissa da objeção é equivocada. Ela põe o debate em um nível inferior àquele que lhe corresponde. Antes de examinar se a garantia judicial de direitos sociais viola o princípio da separação dos poderes, porque implica, na maioria das vezes, na usurpação de competências do Legislativo e do Executivo pelo poder judicial, é preciso averiguar o sentido em que os direitos fundamentais sociais foram acolhidos no nível constitucional. 0 debate precisa ser mais preciso e cuidadoso, porque não se está a estudar um texto cujo significado básico esteja na divisão estrutural de funções da organização estatal, mas na garantia dos bens, interesses e valores individuais e sociais protegidos através da categoria dos direitos fundamentais.

A organização do Estado, a distribuição e limitação do exercício do poder público que é inerente às constituições das democracias contemporâneas não são um

61 ALEXY, Robert, ob. cit, p.412.

62 Cf. BARBER, Sotirius, The Constitution ofAdicial Power, The John Hopkíns University Press, Baltimore, 1993, p. 28; Barber sustenta, no sentido exposto no texto, que para os autores do Federalista a Constituição norte-americana era antes um programa de fins sociais do que um instrumento de restrições governamentais, e portanto a forma institucional da divisão de poderes não se sobrepõe, no pensamento constitucional de Publius, à garantia do bemestar social: "The major point of the polical effort thal produced the Constitution consisted in lhose ends. The restrictions were derivative and secondary, noi fundamental; they were the conduits or channel markers of a dedicated or focused program. These channel markers helved to define the program by setting it aparl from others, and in this way they negated the others. But the system's sense depend primarity on the ends toward which it directed social energy. The Constitution was more of a charter or an enabling act thim a set of restrictions" (p. 109). 
fim em si mesmo. São meramente instrumentais para assegurar à sociedade uma "vida boa", para garantir o ambiente necessário para que os indivíduos busquem e atinjam a sua "felicidade", ou, de modo mais concreto, para assegurar aos indivíduos uma sociedade livre, igualitária e justa.

Por isso o estudo do modelo concreto de constituição é imprescindível para aferir o grau de comprometimento que a sociedade estabeleceu, no momento constituinte, com o princípio majoritário. Isso porque a própria noção moderna de constituição, caracterizada pela sua supremacia institucional sobre as fontes de poder que ela própria organiza e pela rigidez e superioridade normativas em relação à legislação ordinária, já determina um inevitável conflito com o princípio democrático. A rigor, a concepção constitucional de Estado impõe às democracias espaços imunes ou restritivos ao princípio majoritário, daí a permanente tensão entre constitucionalismo e democracia majoritária.

No entanto, os Estados constitucionais contemporâneos não são democracias reguladas por uma constituição. São modelos complexos de organização social, regulados por uma constituição cuja ratio essendi é garantir aos indivíduos, na maior medida possível, igual acesso aos bens, interesses e valores incorporados na categoria constitucional dos direitos fundamentais. A democracia é um desses valores fundamentais, seguramente elementar e constitutivo do modelo social inerente aos Estados constitucionais, mas ainda assim instrumental à garantia dos bens e valores transubstanciados em direitos fundamentais.

Portanto, a advertência célebre de John Marshall, de que "nós não devemos esquecer que é uma constituição que nos estamos aplicando" (we do noi must forget it's a constitution we are expounding), propõe uma compreensão correta do significado das constituições modernas: elas não são instrumentos de governo, ainda que de governos democráticos; são instrumentos de garantia da cidadania e dos direitos fundamentais nelas acolhidos ${ }^{63}$

Assim, é no princípio da supremacia constitucional que reside a legitimidade da concretização dos direitos sociais pelo poder judicial. Quando uma constituição, como a Constituição Federal de 1988, incorpora uma série de direitos sociais e a dota de uma cláusula explícita de auto-aplicabilidade, como o parágrafo $1^{\circ}$ do artigo $5^{\circ}$ da Constituição vigente, há uma clara elevação do acervo jusfundamental do plano de disponibilidade dos poderes constituídos. A garantia efetiva dos direitos sociais passa a ser um dever político compartido por todas as esferas de poder do Estado, e mecanismos destinados a otimizar a tutela do indivíduo, como a separação de poderes e a repartição de competências, não podem ser utilizados para restringir ou impedir a satisfação dessa classe de direitos.

63 Essa é uma visão do Estado constitucional coerente com a teoria da justiça de John Rawls, que, vinculando a organização política de uma sociedade "bem-ordenada" à idéia de justiça que a fundamenta, afirma que "o objeto primário da justiça é a estrutura básica da sociedade ou, mais exatamente, a maneira pela qual as instituições sociais mais importantes distribuem direitos $e$ deveres fundamentais e determinam a divisão de vantagens provenientes da cooperação social", em Teoria da Justiça, Editora Martins Fontes, 1997, pp. 07/08. 
A legitimidade que o poder judicial detém para assegurar a fruição de direitos sociais deriva, pois, diretamente da Constituição, da decisão política do constituinte soberano de 1988 de excluir os direitos sociais do âmbito de competências legislativas e executivas. Os poderes legislativo e administrativo mantém, é claro, o poder de conformação normativa dos direitos sociais, inclusive pela textura aberta com que eles estão redigidos na Lei Fundamental. Mas não está à disposição da discricionariedade legislativa ou administrativa a concretização ou não dos direitos fundamentais sociais. Neste sentido, os direitos sociais recolhidos pela Constituição são mandamentos aos órgãos políticos do Estado, e não meras exortações programáticas, a serem realizadas segundo critérios discricionariamente eleitos pelos poderes constituídos.

Em outras palavras, o fato da decisão tomada pelo soberano, no exercício do poder constituinte, qualificando um determinado bem da vida como um direito, determina uma alteração da natureza do bem e do seu locus e modo de satisfação. $O$ bem da vida convertido em direito fundamental deixa de ser um tema da política e passa a ser uma questão de Direito, e portanto se submete às formas e procedimentos de aplicação e concretização jurídicos. A longa e firme trajetória do Direito no processo civilizatório da humanidade, sobretudo no mundo ocidental, não permite imaginar, salvo quando houver evidências sólidas em contrário, que o constituinte utilizou artificialmente a linguagem jurídica e instrumentos de Direito para acolher pretensões meramente políticas, ou cujo âmbito de solução pertencesse com exclusividade ao território político. Não se pode presumir a irresponsabilidade ou a inconsequiência do legislador constituinte em optar deliberadamente pela artificialidade dos conteúdos constitucionais ${ }^{64}$.

Interessante que a abordagem em exame termina por aproximar as teorias do direito desenvolvidas por Jürgen Habermas e Ronald Dworkin, normalmente consideradas antitéticas ${ }^{65}$. Basta compreender que a teoria discursiva do direito de $\mathrm{Ha}$ bermas não representa um descompromisso com a garantia dos direitos fundamentais, mas, ao contrário, a elaboração de uma concepção procedimentalmente legítima para assegurar as melhores condições possíveis para fazê-los eficazes, e que a teoria construtivista do direito de Dworkin é compatível com uma prática judicial que não atribua ao juiz um papel solipsista na construção da melhor solução para o caso, e que aceite uma elaboração discursivamente aberta e reflexiva da decisão, exatamente porque visa a criar condições racionalmente ideais para a garantia dos direitos fundamentais.

64 E as evidências que justificariam a exceção não parecem presentes no texto constitucional em vigor, que faz uso preciso e claro de categorias jurídicas típicas na instituição de direitos sociais, seja porque os define como direitos fundamentais, porque lhes reserva a cláusula da auto-aplicabilidade, ou ainda porque prevê mecanismos precisos de satisfação política, administrativa e financeira, inseridos por exemplo no sistema tributário constitucional.

65 Ver, por exemplo, CITTADINO, Gisele, Pluralismo, Direito e Justiça Distributiva, e VIANNA, Luiz Werneck e outros, A Judicialização da Política e das Relações Sociais no Brasil, Editora Revan, Rio de Janeiro, 1999, pp. 15/44. 
Um dos cânones chaves da teoria de Dworkin é o princípio da igual consideração e respeito aos indivíduos ${ }^{66}$. Em sua crítica aos originalistas e comunitaristas, correntes doutrinárias que atacam a legitimidade do Poder Judiciário para, através da judicial review, criar novos direitos fundamentais a partir da interpretação do texto constitucional, ele sustenta que a legitimidade da garantia dos direitos pelo poder judicial é respaldada pela sua capacidade de realizar de modo eficaz a igual consideração e respeito aos interesses dos indivíduos:

"O processo político de uma comunidade genuína deve expressar alguma concepção bona fide de igual consideração pelos interesses de todos os membros, o que significa que decisões políticas que afetam a distribuição de riqueza, benefícios e obrigações devem ser consistentes com a igual consideração de todos. A qualidade de membro moral envolve reciprocidade: uma pessoa não é um membro a menos que ela seja tratada como membro pelos outros, o que significa que eles tratam as consequiências de qualquer decisão coletiva para sua vida como uma razão tão igualmente significativa quanto são as consequiências comparáveis para a vida de qualquer outro." 67

Esse ideal é realizado por um processo judicial destinado a discutir as condições de justiciabilidade de um direito fundamental social. Na medida em que o procedimento é aberto e reflexivo, realiza-se no âmbito jurisdicional a harmonização entre a tutela dos direitos fundamentais e o princípio democrático, sem sacrificar um em detrimento do outro. A crítica do caráter antidemocrático da concretização direta dos direitos sociais pelo poder judicial esvaziase em virtude das condições de acesso à justiça e do procedimento de deliberação judicial. O grau de participação e de controlabilidade social dos processos judiciais e das soluções neles encontradas assegura à sociedade a auto-determinação que é hábito encontrar-se - equivocadamente - apenas nos processos legislativos de produção do Direito. Em verdade, a afetação da concretização dos direitos sociais ao Poder Judiciário não enfraquece, e sim enriquece a democracia, como disse Dworkin ${ }^{68}$ por acrescentar no cenário estatal um fórum independente e qualificado de discussão pública.

A percepção de que o Poder Judiciário é portador de virtudes democráticas e portanto não se pode imputarlhe, sob tal pretexto, o déficit de legitimidade para criar direito que sempre se lhe atribuiu está também presente em Mauro Capelletti, para quem "o processo judicial é um núcleo fundamental de democraticidade". "Embora o juiz não seja, e nem deva ser, sujeito à vontade da maioria, resta o jato, extrema-

66 O conceito que Dworkin dá a este princípio é o seguinte: “This principle (egalitarian principle) stipulates that government must act to make the lives of citizens better, and must act with equal concern for the life of each member"; em Sovereign Virtue, The Theory and Practice of Equality, Harvard University Press, Cambridge, 2.000, p. 184

67 DWORKIN. Ronald, Freedom's Law, p. 25.

68 Aqui, imprescindível a leitura de DWORKIN, Ronald, Uma Questāo de Princípio, Editora Martins Fontes, 2000, pp. 3-39. 
mente relevante, que o processo judiciário é essencialmente participatório"69; $\mathrm{e}$ "Um Judiciário razoavelmente independente dos caprichos, talvez momentâneos, da maioria, pode dar uma grande contribuição à democracia, para isso muito mais pode colaborar um Judiciário suficientemente ativo, dinâmico e criativo" ${ }^{70}$. De fato, o próprio modo de exercício das suas funções transforma o Poder Judiciário em um singular fórum democrático, na medida em que os processos judiciais são necessariamente argumentativos e, portanto, devem fazer um uso apropriado da razão pública para justificar as decisões que no seu ambiente são adotadas, ao contrário de decisões políticas tomadas, por exemplo, nas esferas parlamentares, em que a fundamentação racional não prevalece ${ }^{71}$.

Habermas revela certa reserva quanto à capacidade do poder judicial de absorver o papel de regente da vida política de um Estado democrático e parece preferir limitar sua atuação aos casos "nos quais se trata da imposição do procedimento democrático e da forma deliberativa da formação política da opinião e da vontade" ${ }^{72}$. No entanto, se é o próprio poder judicial que se converte em um espaço público democrático e se utiliza de formas deliberativas na formação da vontade política do Estado, então desaparece o seu suposto déficit democrático, extraído da forma convencional do processo judicial, fechado e esquemático.

Em suma, a efetividade dos direitos sociais, ou, por outra via, a possibilidade de extrairse direitos subjetivos justiciáveis a partir das normas constitucionais definidoras de direitos sociais não viola o princípio democrático ou a separação de poderes, em virtude do fato da supremacia da constituição no sistema político de um Estado constitucional. Quando a sociedade, no exercício máximo e decisivo da sua soberania, elabora sua lei fundamental e nela institui um determinado catálogo de direitos fundamentais, ela impõe aos poderes constituídos o dever de concretizálos na melhor e mais ampla medida possível; ela torna os poderes constituídos instrumentais à efetividade dos direitos, e portanto a lógica de funcionamento deles não pode ser pretextada para limitar a eficácia dos direitos fundamentais.

\section{Usurpação de competências}

Uma terceira objeção freqüente à justiciabilidade dos direitos sociais refere-se à inaptidão ontológica da função judicial para decidir questões que envolvem matérias de alta complexidade, compostas por fatores economicos e políticos, e que

69 CAPELLETTI,.Mauro, Costituzionalismo Moderno e Ruolo del Potere Guidiziario nelle Società Contemporanee, Revista de Processo, n. 68, out/dez 1992, p. 51.

70 CAPELLETTI, Mauro, Juizes Legisladores?, Editor Sérgio Fabris, 1993, p. 107.

71 Neste sentido RAWLS, John, Liberalismo Político, Editora Ática, $2^{\mathbf{a}}$ edição, 2000, p. 286.0 conceito sintético de razão pública na obra de Rawls consiste no "debate dos cidadãos no espaço público sobre os fundamentos constitucionais e as questões básicas de justiça", cf. ob. cit., p. 52. 72 HABERMAS, Jürgen, Direito e Democracia, v. 1, pp. 346/347. 
somente podem ser bem equacionadas nas esferas de condução política do Estado, os poderes legislativo e executivo ${ }^{73}$.

Argumenta-se, em regra, que a garantia concreta dos direitos sociais depende da disponibilidade de meios financeiros pelo Estado, e a impossibilidade econômica é um limite inescapável da pretensão de aplicabilidade direta dessa classe de direitos fundamentais ${ }^{74}$. Sustenta Böckenförde que os direitos sociais não contêm em si mesmo nenhum critério acerca da extensão da sua garantia, e não se pode concluir a partir do seu enunciado se se deve garanti-los em um grau mínimo, em um médio ou no grau máximo. E complementa: "Devido à impossibilidade de resolver esses problemas pela via da aplicação judicial do Direito, os direitos fundamentais se reduzem a tarefas constitucionais (Verfassungsaufträge). Vinculam o legislador e $o$ poder executivo só objetivamente, como normas de princípio, mas não fundamentam nenhuma pretensão diretamente ante os tribunais para além da defesa ante uma inatividade abusiva em extremo" 75 .

Essa leitura desiludida e resignada acerca da eficácia potencial dos direitos sociais, francamente predominante na doutrina constitucional e curiosamente em vias de superação no espaço judicial brasileiro, deriva exatamente da concepção estática e semântica das normas constitucionais definidoras de direitos sociais. A fato de que a realização prática da norma, de que a concretização do direito nela enunciado, dependa de viabilização econômica ou de programas governamentais justifica que se considere desde logo impossível a conquista efetiva do direito social pela via judicial. Vale dizer, a própria natureza da norma é abortiva da sua eficácia.

Mas se o processo judicial através do qual pretende-se obter a concretização de um direito social permite uma discussão aberta e reflexiva de todos os afetados pelo conflito, mediante performances discursivas orientadas para o entendimento, então o Estado, sujeito passivo das prestações estatais correspondentes aos direitos fundamentais sociais, terá na esfera pública judicial condições de expor e provar amplamente todos os fatores econômicos, sociais e administrativos que porventura desautorizem ou impeçam a concretização do direito, em um debate conduzido pela

73 Para uma crítica de fundo do deslocamento de questões econômicas e políticas para a esfera judicial, ver DAHRENDORF, Ralf, Ley y orden, Cuadernos Civitas, Madri, 1994, pp. 92/93. Entre nós, José Reinaldo de Lima Lopes revela igual resistência à correção jurídica e política da justiciabilidade de direitos sociais em face dos fatores de organização econômica e financeira atinentes à prestação de serviços públicos, embora com certa ambigüidade, evidenciada em passagem em que parece admitir a legitimidade democrática e a conveniência política da atuação judicial na garantia dos direitos sociais: " $O$ Judiciário, provocado adequadamente, pode ser um poderoso instrumento de formação de políticas públicas." E arremata: "Pela sua natureza, o debate judicial permite o avanço da democracia ao permitir as discussões de temas relevantes. Seja lá qual for a nossa opiniāo a respeito de temas como censura, liberdade de imprensa, aborto, direitos de minorias, direito de greve etc., sua submissão a uma discussão judicial exige, com mais ou menos sucesso, a racionalidade das propostas divergentes." In Direito subjetivo e direitos sociais, cit., pp. 136/137. 74 BÖCKENFÖRDE, Ernst-Wolfgang, Escritos de Derechos Fundamentales, Baden-Baden:Nomos, 1993.

75 BÖCKENFÖRDE, ob. cit., pp. $67 / 68$. 
mediação qualificada de um juiz ou de um tribunal, representantes legítimos da soberania popular para fins de cumprimento da Constituição.

E na hipótese de inviabilização do consenso entre o Estado e o indivíduo, a coletividade ou a instituição pública ou privada que postula a concretização judicial do direito social, a solução será determinada pelo juiz ou pelo tribunal com base nos termos qualificados de uma discussão aprofundada, estabelecida entre as partes e reforçada pela interferência de terceiros que tenham colaborado com participações informativas para propiciar a melhor solução e revelar os melhores argumentos sobre o objeto do processo.

O procedimento de criação da decisão consiste, portanto, em um método construtivista, no estilo proposto por Dworkin, mas sem sobrecarregar a figura do juiz ou do tribunal, porque distribui entre todos os participantes e interessados no caso os encargos de argumentação e produção de provas, dados e informações e o dever de atuar guiado para o entendimento. O solitário Hércules é então substituído por um arquétipo de juiz capaz de fazer a sinergia dos melhores argumentos e das mais relevantes evidências, restringindo ao máximo as ações estratégicas e estimulando as performances comunicativas.

O pronunciamento judicial é, por conseguinte, proferido com elevado nível de racionalidade e de controlabilidade social dos seus fundamentos e das suas conseqüências, circunstâncias suficientes para creditar-lhe legitimidade para impor ao Estado a satisfação do direito social. Os fatores financeiros, orçamentários, administrativos e técnicos terão sido apresentados, debatidos e submetidos a provas e avaliações, de modo a permitir que, na hipótese da manutenção do dissenso entre as partes, a decisão judicial reflita efetivamente uma solução ponderada, que garanta na máxima medida possível a efetividade do direito social, sem impor ao Estado deveres e metas impossíveis de serem atingidas.

No processo de deliberação poderão ser formulados os argumentos da reserva do possível $^{76}$, da reserva legal, dos limites orçamentários e outros destinados a demonstrar a impossibilidade de concretização judicial do direito social reclamado. É evidente que amiúde será possível que o Estado demonstre a necessidade absoluta de legislação para disciplinar a forma e a extensão do direito social, ou a incompatibilidade econômica da pretensão com os recursos financeiros de que dispõe o órgão público, ou ainda a inexistência de estrutura administrativa que possa viabilizar a prestação estatal pretendida. ${ }^{77}$

76 Sobre a reserva do possível e a reserva legal como argumentos contra a eficácia dos direitos sociais, ver SARLET, Ingo Wolfgang, A Eficácia dos Direitos Fundamentais, pp. 259 e ss.

77 Exemplo importante da viabilidade da discussão judicial das limitações financeiras, orçamentárias e administrativas no âmbito de açōes que pretendam concretizar direitos fundamentais ocorreu em ação civil pública cuja apelação foi apreciada pela $4^{a}$ Câmara Cível do Tribunal de Justiça do Estado do Rio Grande do Sul. A ação visava, entre outras medidas protetivas ao meio ambiente, a condenação do Município de Porto Alegre a construir estações de tratamento de todo o esgoto do Município. No seu voto condutor, o relator inicialmente afirma que o julgamento de procedência da demanda não significa o ingresso do Poder Judiciário no mérito administrativo, mas a adequação deste às necessidades da população, preservação da saúde pública e observância de critérios de 
Argumenta-se que a concretização de direitos sociais é um problema de competência, e sendo a competência para administrar ou legislar sobre as prestações estatais que garantem direitos sociais atribuída aos poderes executivo e legislativo, não poderia o poder judicial, por carecer de competência funcional específica, substituir-se àqueles para assegurar a fruição direta do direito. $\mathrm{O}$ argumento não convence. Ninguém discute que a competência para legislar sobre direitos sociais seja do poder legislativo, e que a competência para executar ações administrativas de prestação de direitos sociais pertença ao poder executivo. Ocorre que não é da competência destes poderes decidir se garantirão esses direitos, porque essa é uma determinação constitucional, logo um mandado do soberano que vincula todas as esferas de poder do Estado. E o poder judicial, sendo um organismo criado pelo constituinte para realizar os fins constitucionais, está tão vinculado à Lei Fundamental, e portanto goza da mesma legitimidade, quanto os demais poderes para materializar os direitos sociais instituídos pelo soberano na Constituição.

Em reforço a essa proposta, é de se agregar o argumento de Ingo Wolfgang Sarlet, que interpreta o parágrafo $1^{\circ}$ do artigo $5^{\circ}$ da Constituição Federal, que determina a autoaplicabilidade das normas definidoras de direitos fundamentais, como uma norma de princípio, no sentido da teoria das normas de Dworkin ${ }^{78} \mathrm{e}$ Robert Alexy ${ }^{79}$.

Conforme a hoje amplamente aceita teoria de Alexy, os princípios são mandados de otimização, enquanto as regras são mandados definitivos. Enquanto mandados de otimização, os princípios são normas que ordenam que algo seja realizado na maior medida possível, conforme as possibilidade fáticas e jurídicas do caso, o que significa que podem ser satisfeitos em graus diferentes, de acordo com a necessária ponderação entre o princípio a ser satisfeito e os demais princípios do sistema. Já as regras são normas que sempre devem ser aplicadas, exceto se o próprio sistema normativo contiver exceções à sua incidência. Se uma regra é válida e aplicável, então está ordenado fazer exatamente o que ela exige. Sua aplicação é, pois, uma questão de

oportunidade e conveniência das obras e dotações orçamentárias para elas. A seguir, a Câmara, já decidida quanto à procedência do pedido, discute, com a participação ativa dos três desembargadores, o prazo necessário para a execução da decisão judicial, em face das implicações orçamentárias e dos procedimentos administrativos exigidos para realizar as obras. No debate travado, variou entre 03 e 10 anos o prazo a ser fixado, restando ao final um prazo de 06 anos para o cumprimento da decisão. Da ementa do precedente consta: "Construção de estações de tratamento de todo o esgoto da cidade como forma de preservação da saúde pública. Legitimidade do Poder Judiciário para fixar prazo para realização e conclusão das obras. Necessidade, entretanto, de facultar ao Município a observância de critérios de oportunidade e conveniência, enquadramento em dotações orçamentárias e realização das necessárias licitaçōes - prazo que não pode ser exíguo por essas circunstâncias além daquele de que as obras abrangem todo o Município. Razoabilidade da fixação de 06 anos para a conclusão das obras". Revista da Jurisprudência do Tribunal de Justiça do Rio Grande do Sul, n. 197, p. 274, Apelação Civil n. 597247642, 4² Câmara Cível, j. em 30.12.98.

78 DWORKIN, Ronald, Taking Rights Seriously, Harvard University Press, Cambridge, $17^{\circledR}$ edição, 1997, pp. 14/80.

79 ALEXY, Robert, Teoria de los Derechos Fundamentales, pp. 81 e ss., e El concepto y la validez del derecho, Gedisa Editorial, Barcelona, 1997, pp. 159 e ss. 
tudo ou nada, e sua técnica de atuação é a subsunção, não a ponderação, como ocorre com os princípios ${ }^{80}$.

A adoção do modelo ponderativo de Alexy permitiu a Ingo Sarlet compreender o artigo $5^{\circ}, \S 1^{\circ}$ como uma norma de princípio, primeiro porque ressalta o caráter necessariamente argumentativo da atuação judicial destinada à concretização de direitos sociais, segundo porque remete a verificação da viabilidade de concretização do direito aos fatores, condições e circunstâncias do caso concreto, cujo exame far-se-á através de um juízo de ponderação guiado pelo entendimento e pelo esforço de privilegiar os melhores argumentos, à luz das possibilidades econômicas, sociais e administrativas subjacentes ao problema ${ }^{81}$.

A reserva do possível converte-se, então, em um argumento de princípio a ser contraposto e analisado em contraste com o princípio da autoaplicabilidade das normas definidoras de direitos fundamentais. Em ensaio escrito com o objetivo de contestar a legitimidade política do Poder Judiciário para assegurar diretamente a fruição de direito sociais, Gustavo Amaral paradoxalmente oferece valiosa contribuição para definir o modo de interpretação e aplicação das normas constitucionais de direitos sociais em um processo judicial adequado à ética discursiva. Afirma AMARAL que

\begin{abstract}
"a reserva do possível significa apenas que a concreção pela via Jurisdicional de tais direitos demandará uma escolha desproporcional, imoderada ou não razoável por parte do Estado. Em termos práticos, teria o Estado que demonstrar, judicialmente, que tem motivos táticos razoáveis para deixar de cumprir, concretamente, a norma constitucional assecuratória de prestações positivas. Ao Judiciário competiria apenas ver da razoabilidade e da faticidade dessa razões, sendo defeso entrar no mérito da escolha, se reconhecida a razoabilidade." 82
\end{abstract}

80 ALEXY, Robert, El Concepto y la validez del derecho, p. 162. Merece certa reserva o caráter simplificador que Alexy dispensa ao conceito de princípios jurídicos, que em sua obra ganha um grau de definição muito acentuado, mas perde a riqueza epistemológica que conferem aos princípios, por exemplo, as obras de ESSER, Josef, Princípio y norma en la elaboración jurisprudencial del derecho privado, Bosch Casa Editorial, Barcelona, e de GUASTINI, Riccardo, Teoria e dogmática delle fonti, Editora Giuffré, Milão, 1998. O seu grande mérito, contudo, na esteira da teoria das normas de Dworkin, foi de haver incorporado os princípios à categoria de norma jurídica diretamente aplicável, garantindo-lhes uma eficácia que o positivismo sempre lhes negara, aspecto suficiente para justificar sua adoção para os propósitos deste ensaio. A rigor, as obras doutrinárias de Dworkin e Alexy, aparentadas pela aproximação da Filosofia do Direito ao Direito Constitucional, foram decisivas para a compreensão dos sistemas jurídicos contemporâneos, marcados pela simbiose de modelos historicamente contrapostos, como o Common Law e o Direito romano-germânico, e o jusnaturalismo e o positivismo jurídico, promovendo uma confluência de opostos que resultou no modelo principialista hoje predominante na teoria constitucional, conforme dá conta ZAGREBELSKl, Gustavo, El Derecho dúctil, p. 109.

81 SARLET, Ingo Wolfgang, A Eficácia dos Direitos Fundamentais, pp. 311/321.

82 AMARAL, Gustavo, Interpretação dos Direitos Fundamentais e o Conflito entre Poderes, em Teoria dos Direitos Fundamentais, org. Ricardo Lobo Torres, Ed. Renovar, 1999, pp. 95/1 16. 
Segundo sustenta o autor, haveria uma "presunção de ilegalidade" quando do descumprimento do programa ou da regra constitucional, cabendo ao Estado o ônus da prova de suas razões, que devem então ser apresentadas não como razões de Estado, mas como razões de convencimento para o juízo de ponderação entre os bens em conflito.

A partir da concepção principiológica da cláusula constitucional de autoaplicabilidade dos direitos fundamentais e da idéia de impor ao Estado o ônus da prova da impossibilidade de garantir a fruição do direito social, pode-se inferir que os direitos sociais são direitos prima facie, que são justiciáveis e vinculam os tribunais e juízes, a menos que argumentos em contrário, apresentados pelo sujeito passivo da relação jurídica jusfundamental e submetidos ao debate dialético dos participantes do processo, demonstrem a inviabilidade de garanti-los por decisão judicial ${ }^{83}$. Esse método discursivo de concretização dos direitos fundamentais sociais, guiado pela dogmática jurídica, trafega claramente no quadro teórico da ponderação de bens elaborado por Robert Alexy.

Todavia, a aceitação dessa proposta de justiciabilidade dos direitos sociais, cabendo ao Estado devedor da prestação estatal correspondente o ônus da prova da impossibilidade de satisfação da pretensão, depende de uma revisão da visão estática e semântica que tradicionalmente dirige a hermenêutica constitucional. A transição para um modelo dinâmico e pragmático, que incorpore a teoria discursiva do Direito no pensamento jurídico e nos procedimentos judiciais, agregando-lhe legitimidade democrática pela força da racionalidade inerente aos processos abertos e reflexivos de discussão pública, permitirá superar a atitude resignada e desiludida frente ao dilema da eficácia dos direitos sociais e criar condições para garantir-lhes efetividade, sem comprometer a Democracia e o Estado de Direito.

\section{Considerações finais}

Armado cavaleiro, Dom Quixote logo lançou-se em aventuras pelas terras da Espanha. Mal iniciado nas suas andanças, teve a ocasião de agir em nome da justiça pela primeira vez. É que um jovem ovelheiro, preso a uma árvore, sofria açoites a corrente do lavrador para quem pastoreava. O engenhoso fidalgo interveio de pronto em favor do rapaz, que a ele denunciou a malandragem do patrão, de quem há sete meses não recebia seus soldos. $O$ lavrador, sob a ameaça da lança do cavaleiro, em sua defesa disse que o pastor deixava-lhe escapar uma ovelha ao dia. Decidido, Dom

83 Assim, a concepção pragmática da eficácia dos direitos sociais exposta afasta-se da idéia de justiça procedimental pura e aproxima-se da idéia de justiça procedimental imperfeita, nos termos da teoria política de Rawls. A justiça procedimental pura existe quando não há critério independente para o resultado correto, mas um procedimento correto ou justo que garante a correção ou a justiça do resultado; na justiça procedimental imperfeita "há um critério independente e já determinado do que é justo, sendo possivel criar um procedimento capaz de assegurar um resultado que satisfaça esse critério"; cf. RAWLS, Teoria da Justiça, pp. 89/95. 
Quixote sentenciou em favor do moço, determinando ao seu patrão que fizesse o pagamento de todo o devido. Mas como não tivesse o dinheiro na hora e local, requereu o sentenciado ao cavaleiro que fosse feito o pagamento ao retornarem os dois a casa, e as súplicas e advertências de quebra da palavra que lhe fez o ovelheiro não demoveram Dom Quixote de aceitar a proposta do lavrador. $O$ valoroso fidalgo retomou, então, suas andanças, dirigindo Roncinante ao horizonte cheio de contentamento pela justiça que fizera, enquanto atrás o jovem ovelheiro era outra vez amarrado e açoitado pelo patrão, que do Quixote zombava a bravura ingênua.

Essa passagem da obra clássica de Cervantes ilustra ainda hoje com precisão o pendor narcísico e descompromissado dos juristas em relação à realidade social. $\mathrm{O}$ produto da inteligência jurídica brasileira não está, em regra, direcionado para aumentar a justiça social, mas para satisfazer os desejos de auto-realização intelectual dos juristas. Uma teoria jurídica responsável e uma classe judicial comprometidas com a sociedade a quem servem não podem dar-se por satisfeitas com a tarefa formal de dizer o Direito que é. É preciso fazer o Direito ser. A atitude dos juristas ante uma constituição que projeta uma sociedade fraterna e igualitária, que centra a arquitetura social na garantia de direitos destinados a promover a justiça social não pode ser de renúncia ou de resignação; deve ser a de construir instrumentos culturais capazes de intervir positivamente na afirmação do plano constitucional, o que pressupõe uma mudança da concepção política e jurídica da função judicial.

O estudo propôs uma leitura dos direitos sociais comprometida com sua concretização na esfera judicial, mas uma esfera judicial renovada, oxigenada pela abertura ao discurso racional dos atores sociais, de quem presume sem ingenuidade mas com idealismo o compromisso com a construção de uma sociedade justa. É uma leitura que busca enriquecer a Democracia, e não em sabotá-la, mas que cobra dos juristas uma atitude racionalmente solidária com a sociedade. Dom Quixote precisa fazer justiça ao ovelheiro, não ao seu ego. 